\title{
Southern Ocean Heat Uptake, Redistribution, and Storage in a Warming Climate: The Role of Meridional Overturning Circulation ${ }^{\mathscr{a}}$
}

\author{
WEI LIU \\ Department of Earth Sciences, University of California, Riverside, Riverside, and Scripps Institution of Oceanography, \\ University of California, San Diego, La Jolla, California, and Department of Geology and Geophysics, \\ Yale University, New Haven, Connecticut \\ JIAN LU \\ Pacific Northwest National Laboratory, Richland, Washington \\ SHANG-PING XIE \\ Scripps Institution of Oceanography, University of California, San Diego, La Jolla, California \\ ALEXEY FEDOROV \\ Department of Geology and Geophysics, Yale University, New Haven, Connecticut
}

(Manuscript received 6 November 2017, in final form 8 March 2018)

\begin{abstract}
Climate models show that most of the anthropogenic heat resulting from increased atmospheric $\mathrm{CO}_{2}$ enters the Southern Ocean near $60^{\circ} \mathrm{S}$ and is stored around $45^{\circ} \mathrm{S}$. This heat is transported to the ocean interior by the meridional overturning circulation (MOC) with wind changes playing an important role in the process. To isolate and quantify the latter effect, we apply an overriding technique to a climate model and decompose the total ocean response to $\mathrm{CO}_{2}$ increase into two major components: one due to wind changes and the other due to direct $\mathrm{CO}_{2}$ effect. We find that the poleward-intensified zonal surface winds tend to shift and strengthen the ocean Deacon cell and hence the residual MOC, leading to anomalous divergence of ocean meridional heat transport around $60^{\circ} \mathrm{S}$ coupled to a surface heat flux increase. In contrast, at $45^{\circ} \mathrm{S}$ we see anomalous convergence of ocean heat transport and heat loss at the surface. As a result, the wind-induced ocean heat storage (OHS) peaks at $46^{\circ} \mathrm{S}$ at a rate of $0.07 \mathrm{ZJ} \mathrm{yr}^{-1}\left({ }^{\circ} \text { lat }\right)^{-1}\left(1 \mathrm{ZJ}=10^{21} \mathrm{~J}\right)$, contributing $20 \%$ to the total OHS maximum. The direct $\mathrm{CO}_{2}$ effect, on the other hand, very slightly alters the residual MOC but primarily warms the ocean. It induces a small but nonnegligible change in eddy heat transport and causes OHS to peak at $42^{\circ} \mathrm{S}$ at a rate of $0.30 \mathrm{ZJ} \mathrm{yr}^{-1}\left({ }^{\circ} \text { lat }\right)^{-1}$, accounting for $80 \%$ of the OHS maximum. We also find that the eddyinduced MOC weakens, primarily caused by a buoyancy flux change as a result of the direct $\mathrm{CO}_{2}$ effect, and does not compensate the intensified Deacon cell.
\end{abstract}

\section{Introduction}

Observations reveal a pronounced subsurface warming in the Southern Ocean during the past few decades (e.g., Gille 2002; Purkey and Johnson 2010; Durack et al. 2014; Roemmich et al. 2015). This subsurface warming

Supplemental information related to this paper is available at the Journals Online website: https://doi.org/10.1175/JCLI-D-170761.s1.

Corresponding author: Wei Liu, wei.liu@ucr.edu and increased ocean heat content (OHC) correspond to enhanced ocean heat uptake (Frölicher et al. 2015; Roemmich et al. 2015) and cause the observed sea level rise over the Southern Ocean (Church et al. 2011, 2013). In general, the Southern Ocean heat uptake is important for regional sea level change (van der Veen 1988; Gregory et al. 2001), delayed sea surface temperature response (Bryan et al. 1988; Manabe et al. 1991; Armour et al. 2016), transient climate sensitivity and related feedbacks (Winton et al. 2010; Rose et al. 2014), and understanding the recent global surface warming hiatus (Liu et al. 2016; Chen and Tung 2014). A recent study 
also suggested remote effects of the enhanced heat uptake over the Southern Ocean on tropical rainfall and monsoons (Hwang et al. 2017).

An early modeling study of Manabe et al. (1990) suggested that the Southern Ocean takes up heat in global warming via a reduction in convective ocean heat loss. Gregory (2000) further found that the weakened convection acts to reduce the entrainment of heat into the mixed layer from below and finally leads to a decline in upward diffusion of heat along isopycnals below the mixed layer (also see Huang et al. 2003). In the Southern Ocean interior, the balance is maintained between northward/downward heat transport by the mean flow and southward/upward heat transport by eddies (Gregory 2000). In a warming climate, the heat balance changes, modifying ocean heat uptake and heat distribution (e.g., Griffies et al. 2015). Two primary processes have been proposed for the heat balance change: decrease in southward/upward eddy heat transport (Gregory 2000; Dalan et al. 2005; Hieronymus and Nycander 2013; Morrison et al. 2013), or increase in northward/downward advective heat transport by the time mean flow (Cai et al. 2010; Kuhlbrodt and Gregory 2012; Marshall and Zanna 2014; Bryan et al. 2014; Exarchou et al. 2015). Recently, Morrison et al. (2016) found that both processes could be important. The mean flow and eddy processes dominate, respectively, to the south and north of the main convergence region.

Marshall et al. (2015) simulated a mute Southern Ocean surface warming using an ocean general circulation model forced with a spatially uniform surface flux. But to what extent does the heat taken from the atmosphere and distributed into the ocean interior behave like a passive tracer advected along the mean ventilation pathways? Using a passive tracer technique, Banks and Gregory (2006) concluded that the interior temperature change in the Southern Ocean cannot be explained solely by passive tracer transport along isopycnals, since ocean circulation changes also affect heat distribution (see also Xie and Vallis 2012). Winton et al. (2013) explored this question from a different perspective. Holding ocean circulation fixed, they found that modifying ocean circulation can effectively redistribute heat over the Southern Ocean, which was generally consistent with the results of Banks and Gregory (2006). Both Banks and Gregory (2006) and Winton et al. (2013) discussed the role of ocean circulation changes in Southern Ocean heat uptake and redistribution.

Under anthropogenic forcing, the Southern Ocean circulation is suggested to be primarily affected by surface wind stress changes [e.g., Gillett and Thompson (2003); Fyfe (2006); note here, changes in surface buoyancy forcing also play a role; cf. Sen Gupta et al.
(2009)]. Particularly, observations show a poleward shift and strengthening of Southern Hemisphere westerly winds (Swart and Fyfe 2012) related to ozone depletion (e.g., Gillett and Thompson 2003) and increasing greenhouse gases (e.g., Fyfe 2006), with the southern annual mode (Marshall 2003) shifting toward a higher index state (Thompson and Solomon 2002). The poleward-intensified winds strengthen and displace the Eulerian-mean meridional overturning circulation (MOC), often referred to as the Deacon cell (e.g., Sen Gupta and England 2006; Sen Gupta et al. 2009; Downes and Hogg 2013), although this wind-driven circulation change has been suggested to be partially compensated by an increased eddy activity as a result of enhanced baroclinicity (e.g., Hallberg and Gnanadesikan 2006; Hogg et al. 2008; Farneti et al. 2010; Wolfe and Cessi 2010; Abernathey et al. 2011; Bishop et al. 2016).

To isolate the effects of wind change on the Southern Ocean MOC and heat uptake, and hence temperature and heat storage in a warming climate, several studies (e.g., Oke and England 2004; Fyfe et al. 2007; Spence et al. 2010) perturbed surface wind stress alone using a wind pattern derived from global warming experiments. They found that poleward-intensified winds cause a subsurface warming around $45^{\circ} \mathrm{S}$ via an increased downwelling of warm surface water, and a cooling at higher and lower latitudes. Although these studies confirmed the wind effect on heat uptake and redistribution in the Southern Ocean, they could not rigorously quantify this effect by means of a consistent heat budget analysis, as they used either forced ocean general circulation models (Oke and England 2004) or ocean models coupled to an energy balance model of the atmosphere (Fyfe et al. 2007; Spence et al. 2010). Therefore, the ocean-atmosphere coupling was missing or distorted. For example, wind-induced changes in sea surface temperature (SST) and surface heat flux will feed back on the atmospheric storm tracks, precipitation, and clouds. It is essential to consider such feedbacks when examining ocean heat uptake.

In this study, we employ an overriding technique ( $\mathrm{Lu}$ and Zhao 2012; Liu et al. 2015) to isolate and quantify the effects of wind change and related feedbacks on Southern Ocean heat uptake and redistribution. For example, we override surface winds in a fully coupled system from a quadrupled $\mathrm{CO}_{2}$ climate and separate the wind-induced feedback from other feedbacks in term of contributions to the total climate response. Unlike previous studies, our overriding method can practically disable the wind change effect while allowing other atmospheric processes to be fully interactive with the ocean. This allows us to estimate the wind-induced feedback along with the direct $\mathrm{CO}_{2}$ effect and quantify 
TABLE 1. Ten CMIP5 climate models and their variables used in this study. BSF denotes barotropic streamfunction, SHF denotes net surface heat flux, and $T$ denotes ocean temperature. MOC and meridional OHT include components induced by Eulerian-mean flow, eddies, and other processes, while all these components are only available in ACCESS1.0, ACCESS1.3, and CCSM4; we thus only include the MOC and OHT from the above three models in the analysis. Surface winds denote winds at $10 \mathrm{~m}$ above sea surface. Wind velocities (vectors), that is, $(U, V)$ and magnitude of wind speed (Wspd) are available in most models. (Expansions of model acronyms are available online at http://www.ametsoc.org/PubsAcronymList.)

\begin{tabular}{lcccccc}
\hline \multicolumn{1}{c}{ Model } & BSF & SHF & $T$ & MOC & OHT & $(\mathrm{U}, \mathrm{V})$ \\
\hline ACCESS1.0 & $\sqrt{ }$ & $\sqrt{ }$ & $\sqrt{ }$ & $\sqrt{ }$ & $\sqrt{ }$ & $\sqrt{ }$ \\
ACCESS1.3 & $\sqrt{ }$ & $\sqrt{ }$ & $\sqrt{ }$ & $\sqrt{ }$ & $\sqrt{ }$ & $\sqrt{ }$ \\
BCC_CSM1.1 & $\sqrt{ }$ & $\sqrt{ }$ & $\sqrt{ }$ & - & - & $\sqrt{ }$ \\
CCSM4 & $\sqrt{ }$ & $\sqrt{ }$ & $\sqrt{ }$ & $\sqrt{ }$ & $-\sqrt{ }$ \\
GISS-E2-R & $\sqrt{ }$ & $\sqrt{ }$ & $\sqrt{ }$ & - & - & $\sqrt{ }$ \\
HadGEM2-ES & $\sqrt{ }$ & $\sqrt{ }$ & $\sqrt{ }$ & - & - & $\sqrt{ }$ \\
IPSL-CM5A-LR & $\sqrt{ }$ & $\sqrt{ }$ & $\sqrt{ }$ & - & - & $\sqrt{ }$ \\
IPSL-CM5A-MR & $\sqrt{ }$ & $\sqrt{ }$ & $\sqrt{ }$ & - & - & $\sqrt{ }$ \\
MRI-CGCM3 & $\sqrt{ }$ & $\sqrt{ }$ & $\sqrt{ }$ & - & - & $\sqrt{ }$ \\
NorESM1-M & $\sqrt{ }$ & $\sqrt{ }$ & $\sqrt{ }$ & - & & $\sqrt{ }$ \\
\hline
\end{tabular}

its contribution to the Southern Ocean heat uptake and redistribution through a consistent heat budget analysis.

The structure of the paper is as follows. In section 2, we introduce the models, experiments, and metrics used in this study, with a particular emphasis on the overriding technique. We present the main results in section 3 , and present the paper's conclusions and discussion in section 4.

\section{Methods}

\section{a. CMIP5 models and simulations}

To study the characteristics of Southern Ocean heat uptake and redistribution to increasing $\mathrm{CO}_{2}$, we analyze the preindustrial control (piControl) and abruptly quadrupled $\mathrm{CO}_{2}$ (abrupt4xCO2) simulations of 10 climate models (Table 1) participating in phase 5 of the Coupled Model Intercomparison Project (CMIP5; Taylor et al. 2012). The abruptly quadrupled $\mathrm{CO}_{2}$ represents an idealized global warming scenario in which the atmospheric concentration of $\mathrm{CO}_{2}$ is instantaneously quadrupled from its initial preindustrial value and then held fixed. We examine the changes of several variables (Table 1) that are related to Southern Ocean heat uptake and redistribution. For each variable, the change is defined as the difference between years 41-90 after $\mathrm{CO}_{2}$ quadrupling and a 50-yr average in piControl. Note here, our analysis of the change over years $41-90$ is an investigation of the transient climate response to $\mathrm{CO}_{2}$ increase, since the abyssal ocean will need thousands of years to reach equilibrium after quadrupled $\mathrm{CO}_{2}$. It also merits attention that the Southern Ocean SST, and therefore heat uptake and storage, show a fast (over years) and slow (over decades) response to a given forcing (Ferreira et al. 2015; Kostov et al. 2017), whereas our choice of change over years 41-90 does not account for the fast response.

In our analysis, most variables are available across the 10 models (Table 1). For the eddy-induced MOC and meridional ocean heat transport, both of them are only available in ACCESS1.0, ACCESS1.3, and CCSM4. Thus, we just use these three models for MOC and heat transport analyses. Besides, we only analyze the first member run (r1i1p1) of each model to ensure equal weight in intermodel analysis.

\section{b. CESM and overriding experiments}

We use the Community Earth System Model (CESM; Hurrell et al. 2013), version 1.0.5, from the National Center for Atmospheric Research (NCAR) that includes the latest version of the Community Atmosphere Model, version 5 (CAM5; e.g., Neale et al. 2012), the Community Land Model, version 4 (CLM4; Lawrence et al. 2012), the Community Ice Code, version 4 (CICE4; Holland et al. 2012), and the Parallel Ocean Program, version 2 (POP2; Smith et al. 2010), and henceforth the coupled model is called CESM1(CAM5). The f19gx1v6 configuration used here has a finite-volume dynamical core (Lin 2004) with a nominal $2^{\circ}$ atmosphere and land horizontal grid $\left(1.9^{\circ}\right.$ latitude $\times 2.5^{\circ}$ longitude $)$ with 26 atmospheric layers in the vertical, and a nominal $1^{\circ}$ ocean and ice horizontal grid (referred to as $\mathrm{x} 1$ ) with 60 ocean layers in the vertical. Over the Southern Ocean, the meridional resolution of POP2 is about $0.5^{\circ}$. Although the ocean model is not eddy resolved, it employs a variable coefficient in the Gent-McWilliams eddy parameterization (Gent and McWilliams 1990, hereafter GM), which enables an appropriate ocean response to wind change as indicated in eddy-resolving models (Gent and Danabasoglu 2011). For tracers, such 
TABLE 2. Design of the CESM1(CAM5) overriding experiments. Two baseline runs are CTRL and $4 \times \mathrm{CO}_{2}$. Based on these two runs, five overriding experiments are conducted to isolate and quantify the wind effect and the direct $\mathrm{CO}_{2}$ effect. The overriding variables from CTRL and $4 \times \mathrm{CO}_{2}$ are first output for overriding purpose at the frequency of air-sea coupling. To eliminate the climate drift due to overriding a 1-yr shift is applied to the prescribed overriding variables as indicated in parentheses. The differences between individual pairs of overriding experiments reveal the contributions resulting from Wstr, Wspd, and the dirCO $\mathrm{CO}_{2}$ effect. The total climate response $\left(4 \times \mathrm{CO}_{2}\right.$ minus CTRL) can be replicated by SUM.

\begin{tabular}{|c|c|c|c|c|}
\hline Expt & Wind stress (1-yr shift) & Wind speed (1-yr shift) & $\mathrm{CO}_{2}$ & Purpose \\
\hline 1) CTRL & $1 \times($ no) & $1 \times($ no $)$ & $1 \times$ & Baseline \\
\hline 2) $\tau 1 \mathrm{w} 1 \mathrm{c} 1$ & $1 \times($ yes $)$ & $1 \times($ yes $)$ & $1 \times$ & $\operatorname{dirCO}_{2}$ effect \\
\hline 3) $\tau 1 \mathrm{w} 1 \mathrm{c} 4$ & $1 \times($ yes $)$ & $1 \times($ yes $)$ & $4 \times$ & $\begin{array}{l}\operatorname{dirCO} \mathrm{C}_{2} \text { effect } \\
(\text { expt } 3-\text { expt } 2)\end{array}$ \\
\hline 4) $\tau 4 \mathrm{w} 1 \mathrm{c} 4$ & $4 \times($ yes $)$ & $1 \times($ yes $)$ & $4 \times$ & $\begin{array}{l}\text { Wstr effect } \\
\text { (expt } 4-\text { expt } 3)\end{array}$ \\
\hline 5) $\tau 1 \mathrm{w} 4 \mathrm{c} 4$ & $1 \times($ yes $)$ & $4 \times($ yes $)$ & $4 \times$ & $\begin{array}{l}\text { Wspd effect } \\
\text { (expt } 5 \text { - expt } 3)\end{array}$ \\
\hline 6) $\tau 4 \mathrm{w} 4 \mathrm{c} 4$ & $4 \times($ yes $)$ & $4 \times($ yes $)$ & $4 \times$ & $\begin{array}{l}\text { Replication (SUM) } \\
(\operatorname{expt} 6-\operatorname{expt} 2) \text { vs }(\operatorname{expt} 7-\operatorname{expt} 1)\end{array}$ \\
\hline 7) $4 \times \mathrm{CO}_{2}$ & $4 \times($ no $)$ & $4 \times($ no $)$ & $4 \times$ & Baseline \\
\hline
\end{tabular}

as temperature, the horizontal diffusion follows the Redi isoneutral diffusion operator by the GM parameterization and the vertical diffusion (mixing) follows the K-profile parameterization (KPP; cf. Large et al. 1994).

The baseline runs of this study are a preindustrial control run (CTRL) and a quadruple $\mathrm{CO}_{2}$ run $\left(4 \times \mathrm{CO}_{2}\right)$, which are identical to the piControl and abrupt $4 \times \mathrm{xCO} 2$ simulations by CMIP5 models. Here, we rename these two CESM runs for the convenience of discussion. CTRL is taken from the NCAR CESM1(CAM5) f19gx1v6 configuration in the preindustrial AD 1850 scenario, and $4 \times \mathrm{CO}_{2}$ branches from CTRL, with the atmospheric $\mathrm{CO}_{2}$ concentration instantly quadrupled from the 1850 level and kept constant through the 90-yr simulation.

In contrast to previous wind perturbation experiments, we employ a partial coupling based on the socalled overriding technique ( $\mathrm{Lu}$ and Zhao 2012; Liu et al. 2015) in order to isolate and quantify the contributions of various feedbacks and processes to the Southern Ocean heat uptake and redistribution. The partially coupled CESM1(CAM5) is realized through overriding the time series of one or more variables at the air-sea interface from a fully coupled run to disable the targeted process or feedback. Specifically, it is implemented in the following steps. Let us denote the coupled baseline runs as $\mathrm{c} 1 \mathrm{x}$ for CTRL and as $\mathrm{c} 4 \mathrm{x}$ for $4 \times \mathrm{CO}_{2}$, and the overriding variables from these two runs are first output for overriding purpose at the frequency of air-sea coupling [daily for the case of CESM1(CAM5)] and will be referred to, respectively, as var1x and var4x, in which "var" is the overriding variable. In the paper, we consider three variables: wind stress $(\tau)$, wind speed (w), and $\mathrm{CO}_{2}$ (c) because winds can affect surface heat uptake and interior ocean heat distribution either by changing ocean circulation via surface wind stress or by modifying ocean-atmosphere thermal coupling through the wind speed in the bulk formula of turbulent (latent and sensible) heat fluxes. Next, we conduct a suite of overriding experiments (Table 2) to isolate the effect of the variable we are interested in. For example, to target climate response without wind feedback, we run the $4 \times \mathrm{CO}_{2}$ experiment again but with wind stress and wind speed prescribed from CTRL. We name this overriding run $\tau 1 \mathrm{w} 1 \mathrm{c} 4$, denoting wind stress and wind speed from c1x but $\mathrm{CO}_{2}$ level from $\mathrm{c} 4 \mathrm{x}$.

Inevitably, overriding interferes with the temporal coherence between the overriding variable and the processes it interacts with, leading to a climate drift. For instance, if we were overriding the surface wind in the c1x case by prescribing $\tau 1 \mathrm{x}$ and w1x (but shifted by $1 \mathrm{yr}$ intentionally), the resultant climate (labeled as $\tau 1 \mathrm{w} 1 \mathrm{c} 1$ ) would not be the same as that of $c 1 x$, the difference between them being the drift resulting from overriding wind stress and wind speed (denoted by $\tau 1 \mathrm{w} 1 \mathrm{c} 1-$ CTRL). Here, the 1-yr (or any integer number of years) shift in the time of $\tau 1 \mathrm{x}$ is intended to disrupt its coherence with other fields in the $\mathrm{c} 1 \mathrm{x}$ run; an overriding of $\tau 1 \mathrm{x}$ without the time shift would be simply a replication of c1x. This drift must be identified and excluded in the attribution of the relevant feedbacks, which can be achieved by comparing the overriding runs because the same overriding-induced drift is present in all such runs and the difference between any two of them should eliminate the drift. For example, the direct $\mathrm{CO}_{2}$ effect in quadrupled $\mathrm{CO}_{2}$ climate change simulations should be isolated through the operation $(\tau 1 \mathrm{w} 1 \mathrm{c} 4-\mathrm{CTRL})$, which is the same as $(\tau 1 \mathrm{w} 1 \mathrm{c} 4-\tau 1 \mathrm{w} 1 \mathrm{c} 1)$. Therefore, the climate drifts, which should not be one part of the 
response, are eliminated by the cancellation of drifts in both $(\tau 1 \mathrm{w} 1 \mathrm{c} 4-\mathrm{CTRL})$ and $(\tau 1 \mathrm{w} 1 \mathrm{c} 1-\mathrm{CTRL})$. As a result, this allows a more accurate estimate of surface heat flux and interior ocean heat distribution.

In summary, the overriding technique enables a linear decomposition of the total response to $\mathrm{CO}_{2}$ quadrupling in the fully coupled model into the parts related to: (i) surface wind stress change ( $\tau 4 \mathrm{w} 1 \mathrm{c} 4-\tau 1 \mathrm{w} 1 \mathrm{c} 4)$; (ii) surface wind speed change $(\tau 1 \mathrm{w} 4 \mathrm{c} 4-\tau 1 \mathrm{w} 1 \mathrm{c} 4)$; and (iii) the direct $\mathrm{CO}_{2}$ effect without wind changes ( $\tau 1 \mathrm{w} 1 \mathrm{c} 4-$ $\tau 1 \mathrm{w} 1 \mathrm{c} 1)$. As will be shown in later sections, the surface wind speed change has a minimal effect on Southern Ocean heat uptake and redistribution.

\section{c. $M O C$}

The Eulerian-mean MOC is calculated by integrating Eulerian mean meridional velocity $\bar{v}$ zonally and vertically:

$$
\bar{\psi}(y, z)=\oint \int_{z}^{0} \bar{v} d z^{\prime} d x,
$$

where $x, y$, and $z$ are the zonal, meridional, and vertical coordinates. This representation of the MOC is largely made up of the wind-driven Ekman circulation known as the Deacon cell (Döös and Webb 1994). Similarly, the eddy-induced MOC is calculated as

$$
\psi^{*}(y, z)=\oint \int_{z}^{0} v^{*} d z^{\prime} d x
$$

where $v^{*}$ is eddy-induced velocity. In the POP2 ocean model, it is in form of a bolus velocity derived from the GM parameterization. In the Southern Ocean, there is a partial compensation between Eulerian-mean and eddy-induced MOCs (e.g., Marshall and Radko 2003), yielding a residual $\mathrm{MOC} \psi_{\text {res }}$ as

$$
\psi_{\mathrm{res}}=\bar{\psi}+\psi^{*} .
$$

\section{d. Oceanic heat budget}

The zonally integrated full-depth oceanic heat budget is

$$
\begin{aligned}
& \oint \int_{-H}^{0} \rho_{0} C_{p} \frac{\partial \theta}{\partial t} d z^{\prime} d x+\oint \int_{-H}^{0} \rho_{0} C_{p}[\nabla \cdot(\mathbf{v} \theta+D)] d z^{\prime} d x \\
& \quad=\oint(\mathrm{SHF}) d x,
\end{aligned}
$$

where $\rho_{0}$ is seawater density, $C_{p}$ is the specific heat of seawater, $\theta$ is potential temperature of seawater, and $-H$ denotes the depth of ocean bottom. SHF denotes net surface heat flux, which is the sum of radiative shortwave (SW) and longwave (LW) fluxes and turbulent sensible (SH) and latent ( $\mathrm{LH})$ heat fluxes. The three-dimensional gradient operator is $\nabla$, and $\mathbf{v}$ is the three-dimensional velocity, with $\mathbf{v}=\overline{\mathbf{v}}+\mathbf{v}^{*}$. The variable $D$ denotes diffusion and other subgrid processes.

Based on Eq. (4), we define the rate of integrated $\mathrm{OHC}$ as ocean heat storage, that is,

$$
\mathrm{OHS}=\frac{\partial}{\partial t} \oint \int_{-H}^{0} \rho_{0} C_{p} \theta d z^{\prime} d x
$$

and ocean heat uptake as

$$
\mathrm{OHU}=\oint(\mathrm{SHF}) d x
$$

and meridional ocean heat transport as

$$
\begin{aligned}
\mathrm{OHT} & =\oint \int_{-H}^{0} \rho_{0} C_{p}\left(\overline{\mathbf{v}} \theta+\mathbf{v}^{*} \theta+D\right) d z^{\prime} d x \\
& =\overline{\mathrm{OHT}}+\mathrm{OHT}^{*}+\mathrm{OHT}^{d},
\end{aligned}
$$

where $\quad \overline{\mathrm{OHT}}=\oint \int_{-H}^{0} \rho_{0} C_{p} \overline{\mathbf{v}} \theta d z^{\prime} d x, \quad \mathrm{OHT}^{*}=$ $\oint \int_{-H}^{0} \rho_{0} C_{p} \mathbf{v}^{*} \theta d z^{\prime} d x$, and $\mathrm{OHT}^{d}=\oint \int_{-H}^{0} \rho_{0} C_{p} D d z^{\prime} d x$. Equation (7) shows that meridional ocean heat transport $(\mathrm{OHT})$ can be induced by Eulerian-mean flow $(\overline{\mathrm{OHT}})$, eddies $\left(\mathrm{OHT}^{*}\right)$, and diffusion $\left(\mathrm{OHT}^{d}\right)$. Therefore, the heat budget by Eq. (4) can be written as

$$
\mathrm{OHS}=\mathrm{OHU}-\frac{\partial}{\partial y} \mathrm{OHT},
$$

which indicates that ocean heat storage is determined by heat uptake from atmosphere-ocean interface and heat retribution by ocean circulation via the meridional gradient of ocean heat transport.

\section{Results}

\section{a. Climate response in CMIP5 models}

We first examine the change of SHF and OHU over the Southern Ocean in response to quadrupled $\mathrm{CO}_{2}$ in CMIP5 models. We find that most heat enters the Southern Ocean over and slightly to the south of the region of the Antarctic Circumpolar Current (ACC) as the deep upwelled water keeps the surface ocean from warming. Particularly, anomalous heat enters (leaves) the ocean in zonal bands along the southern (northern) flank of the ACC (Fig. 1a). This SHF change is due primarily to the sensible and latent heat fluxes (Fig. 1c) that respond to changing air-sea temperature gradients (Frölicher et al. 2015). To the south of the ACC, the 

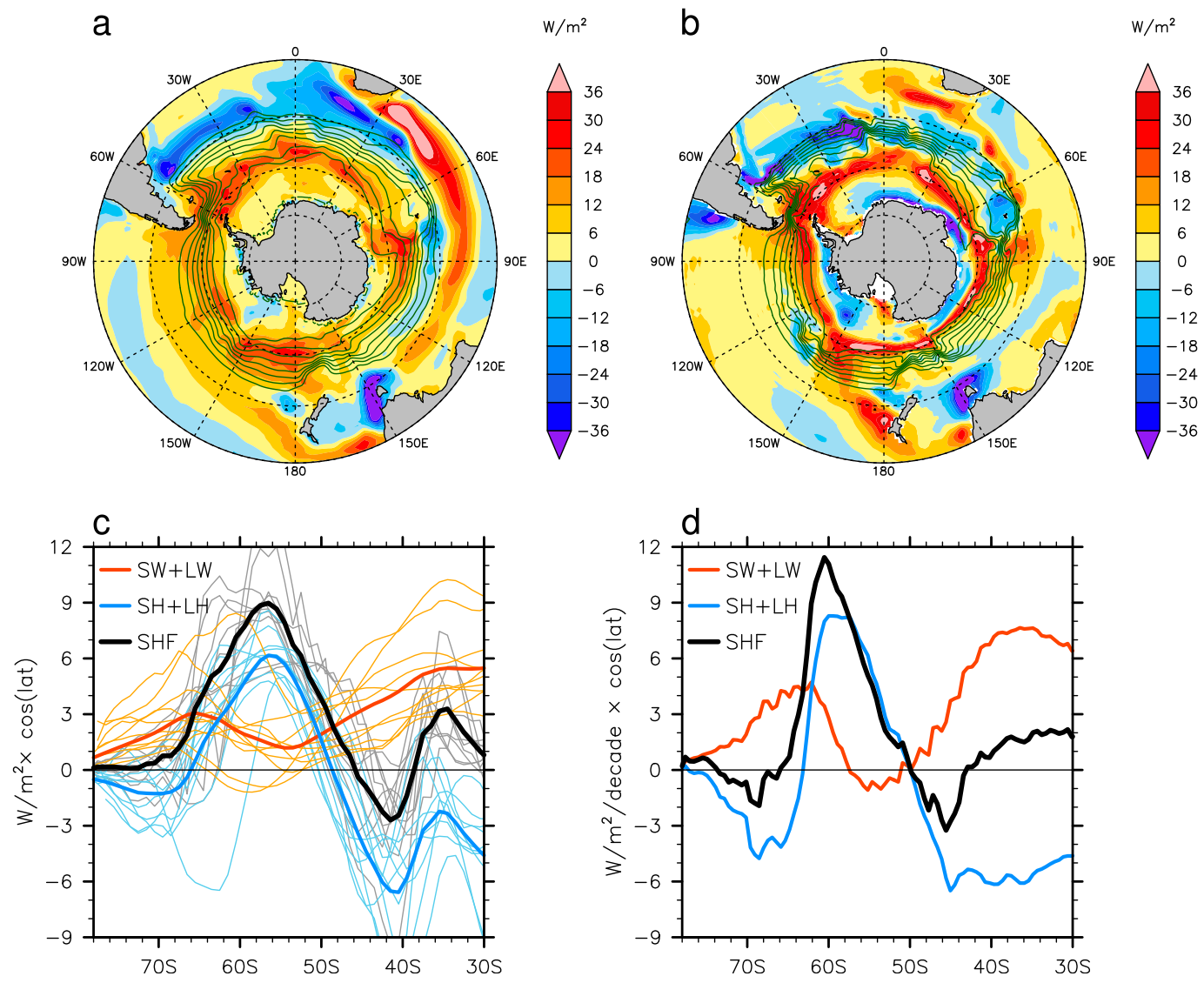

FIG. 1. Changes of SHF over the Southern Ocean in response to quadrupled $\mathrm{CO}_{2}$ (relative to preindustrial control) for (a) CMIP5 model ensemble mean and (b) CESM1(CAM5), with the path of the ACC superimposed that is represented by the contours (green) of BSF from CMIP5 model ensemble mean in (a) and CESM1(CAM5) in (b). Zonal-mean changes (weighted by cosine of latitude) of SHF (black) and its radiative (SW + LW; orangered) and turbulent ( $\mathrm{SH}+\mathrm{LH}$; blue) flux components for (c) CMIP5 model ensemble mean and (d) CESM1 (CAM5). Results of individual CMIP5 models are also included in (c), which are colored gray for SHF, orange for $\mathrm{SW}+\mathrm{LW}$, and light blue for $\mathrm{SH}+\mathrm{LH}$.

atmosphere has warmed more rapidly than the ocean surface such that less heat is lost from the ocean to the atmosphere. In the vicinity of the ACC and north of it, the ocean surface has warmed more rapidly than the atmosphere, with an oceanic heat loss.

Although heat is gained at the southern flank of the ACC (around $60^{\circ} \mathrm{S}$ ), the OHS change peaks at around $45^{\circ} \mathrm{S}$ (Fig. 2a) and is concentrated in the upper $1000 \mathrm{~m}$ (Fig. 2e), which is consistent with previous studies (e.g., Frölicher et al. 2015; Armour et al. 2016). The CMIP5 models appear to agree on this aspect as well (Fig. 2c). The mismatch between the location of OHU and OHS can be attributed to the MOC $\left(\psi_{\text {res }}\right)$ that redistributes heat via OHT divergence or convergence in the Southern Ocean (Frölicher et al. 2015; Armour et al. 2016). Moreover, the full MOC in the Southern Ocean undergoes changes in a warming climate. Southern Hemisphere westerly winds strengthen and displace poleward in response to quadrupled $\mathrm{CO}_{2}$ (Figs. 3a,c), which intensifies and shifts poleward the wind-driven Deacon cell (Fig. 4a). However, the eddy-induced MOC does not correspondingly intensify to compensate for the variation in the Deacon cell, but weakens instead (Fig. 4c). This eddy-induced MOC weakening, as will be shown in later sections, is primarily caused by the surface buoyancy flux change as a result of the direct $\mathrm{CO}_{2}$ effect rather than the wind change. Over the Southern Ocean, changes in the wind-driven $\bar{\psi}$ and eddy-induced $\psi^{*}$ MOCs together result in a stronger and polewardshifted $\psi_{\text {res }}$ (Fig. 4e).

To summarize, CMIP5 models show that the Southern Ocean primarily receives heat from the atmosphere around $60^{\circ} \mathrm{S}$. This incoming heat is redistributed by the residual MOC and mostly stored around $45^{\circ} \mathrm{S}$. Various feedbacks, including the wind-induced feedback, play a role in modifying OHU, OHT, and thus OHS. In the 

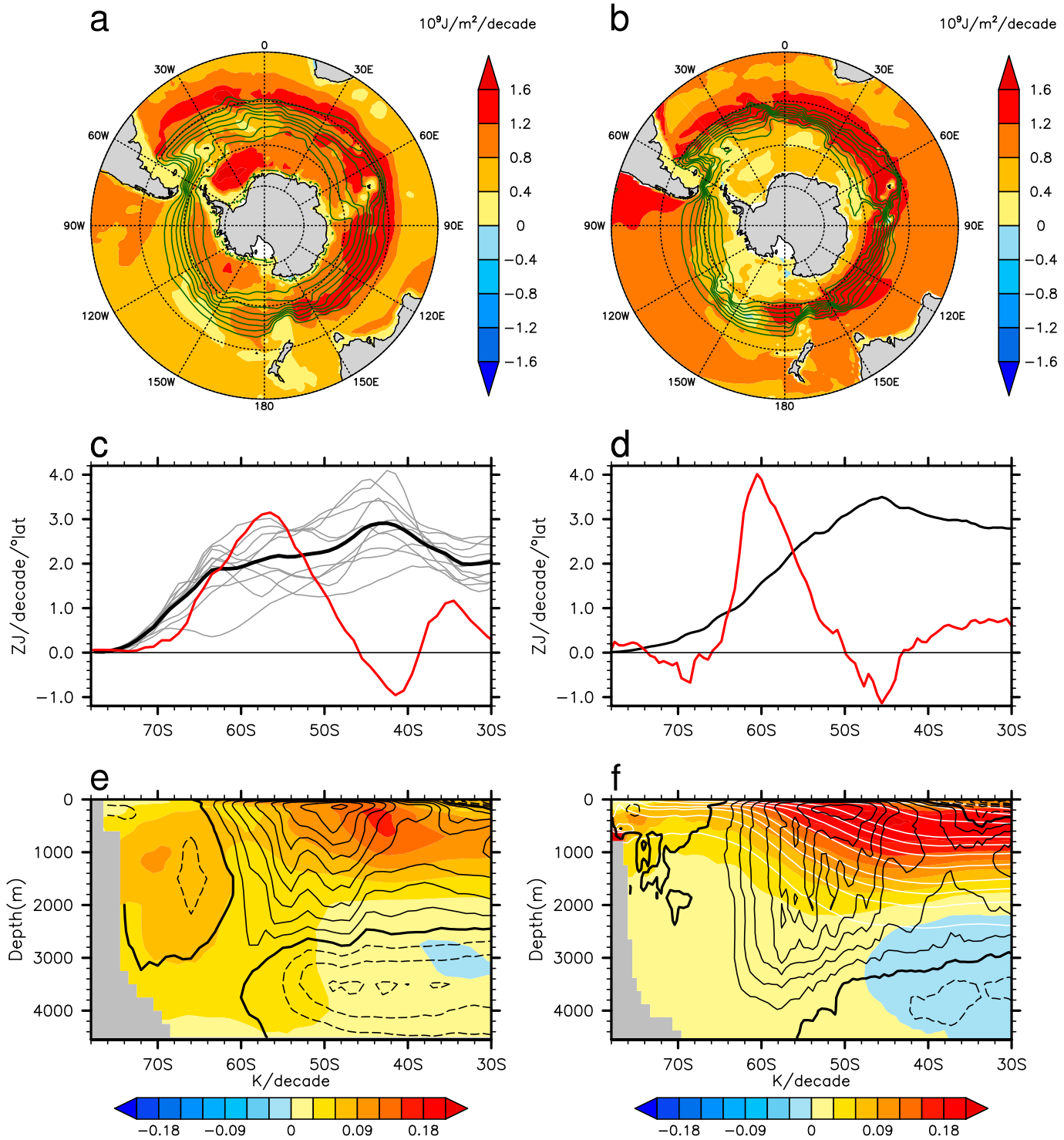

FIG. 2. Trend differences of full-depth integrated $\mathrm{OHC}$ over the Southern Ocean in response to quadrupled $\mathrm{CO}_{2}$ (year 41-90 trend in quadrupled $\mathrm{CO}_{2}$ minus 50-yr trend in preindustrial control) for (a) CMIP5 model ensemble mean and (b) CESM1(CAM5), with (c),(d) their zonal integrals (black), respectively. The ACC path (denoted by BSF contours; green) is included in (a) and (b), and changes of zonal integrals of SHF (scaled by one-fourth; red) are included in (c) and (d). Also, individual CMIP5 model results (gray) are included in (c). Trend differences of zonal mean temperature trend over the Southern Ocean in response to quadrupled $\mathrm{CO}_{2}$ for (e) CMIP5 model ensemble mean and (f) CESM1(CAM5). The preindustrial annual-mean MOC (black contours; contouring scheme follows Fig. 4e) is included in (e) and (f). The preindustrial potential density referenced to the surface $\sigma_{0}$ (white contours; contouring scheme follows Fig. 6a) is included in (f).

next section, we will employ an overriding technique to isolate and quantify the effects of these feedbacks.

\section{b. Decomposed response in the CESM overriding experiments}

Making use of the overriding experiments (Table 2), we decompose the total climate response in CESM1(CAM5) into the parts due to wind stress change (Wstr), surface wind speed change (Wspd), and direct $\mathrm{CO}_{2}$ effect $\left(\operatorname{dirCO}_{2}\right)$ without any wind changes. The sum of these three parts (SUM) closely replicates the total response (see Figs. S1-S3 in the supplemental material; see also Figs 8 and 10). Since the wind speed change has an ignorable contribution to SHF and OHT variations (see Figs. S1-S3 and Figs 8 and 10), we will only focus on the wind stress effect and the direct $\mathrm{CO}_{2}$ effect in the following. 

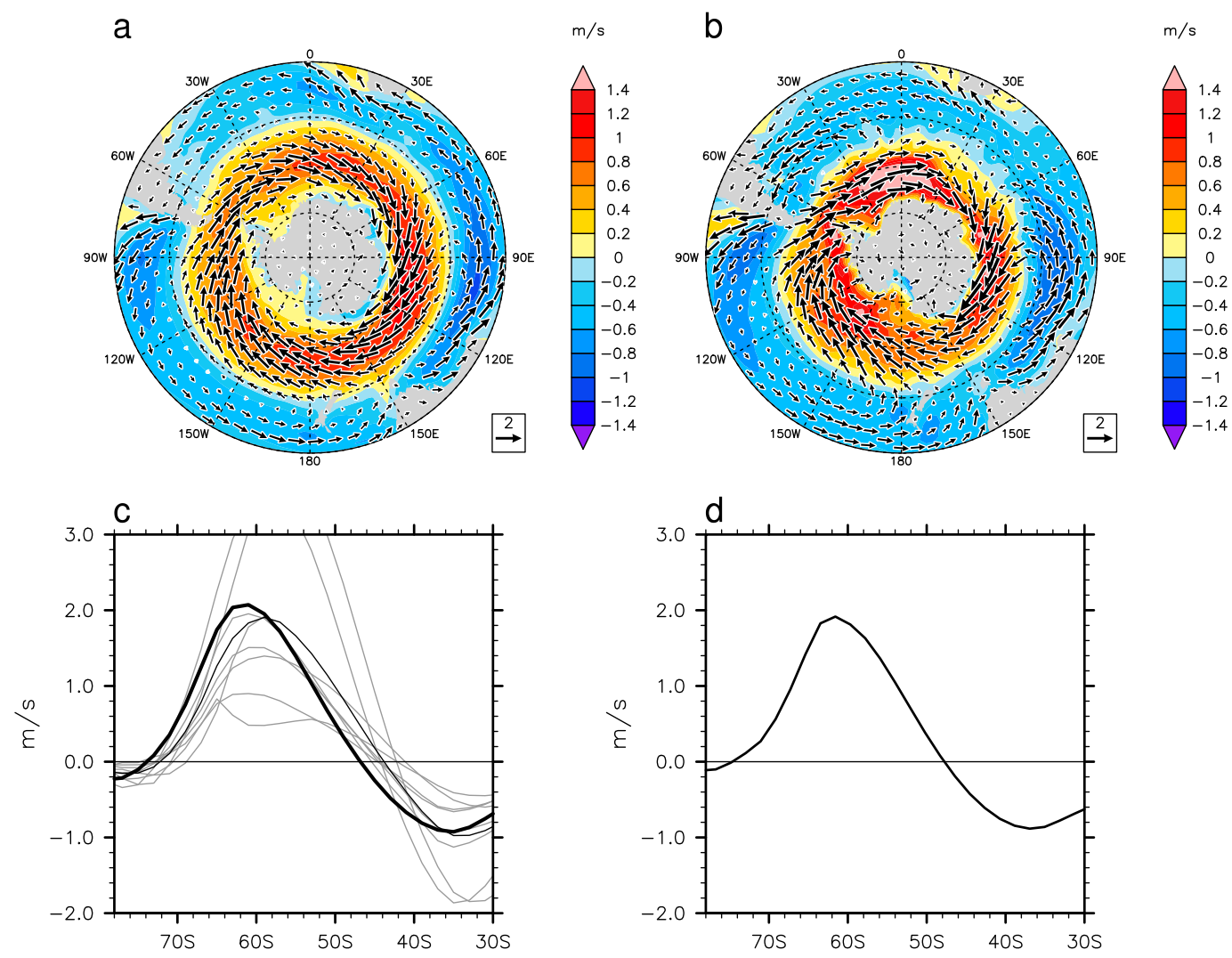

FIG. 3. Changes of annual mean surface winds (vectors) and wind speed (shading) over the Southern Ocean in response to quadrupled $\mathrm{CO}_{2}$ for (a) CMIP5 model ensemble mean and (b) CESM1(CAM5). Zonal-mean profiles of zonal wind change (black) for (c) CMIP5 model ensemble mean and (d) CESM1(CAM5). In (b), the surface winds of CESM1(CAM5) are taken from the bottom level of CAM5 ( $993 \mathrm{hPa})$ while wind speed is at $10 \mathrm{~m}$. In (c), individual CMIP5 model results (gray) are included.

We start with comparing the wind and direct $\mathrm{CO}_{2}$ effects on MOC response to quadrupled $\mathrm{CO}_{2}$. The poleward-intensified wind stress shifts the Deacon cell $(\bar{\psi})$ poleward (in Wstr) and strengthens the cell by about $7 \mathrm{~Sv}\left(1 \mathrm{~Sv}=10^{6} \mathrm{~m}^{3} \mathrm{~s}^{-1}\right)$ at its maximum (Fig. 5e). The $\psi^{*}$ is enhanced because of increased isopycnal tilting and baroclinicity (Fig. 6b), and partially offsets the winddriven Deacon cell (Fig. 5f). Consequently, the $\psi_{\text {res }}$ generally follows the changes in the Deacon cell, producing a poleward-intensified circulation (Fig. 5d). On the other hand, the direct $\mathrm{CO}_{2}$ effect is of secondary importance in modifying the residual MOC (Fig. 5g). It flattens the isopycnal slope (Fig. 6c) and weakens the eddy-induced component of the MOC (Fig. 5i). However, this reduction in the eddy component is compensated (or overcompensated around $60^{\circ} \mathrm{S}$ ) by a decrease in the mean-flow part (Fig. 5h).

Unlike the MOC response, the direct $\mathrm{CO}_{2}$ effect has a much larger contribution to temperature response than the wind stress. Over the Southern Ocean, the total temperature response shows that the surface layers warm by over $3 \mathrm{~K}$, and the warming decays with depth (Fig. 7a). The strongest penetration of the surface signal into the deeper ocean is around $45^{\circ} \mathrm{S}$, where the downward Ekman pumping is strongest. The direct $\mathrm{CO}_{2}$ effect produces a similar warming pattern (Fig. 7c) as the total response (Fig. 7a) and explains most of the warming. The wind stress changes also contribute to a subsurface warming but of a relatively small amplitude. By strengthening and shifting the Deacon cell, and hence the residual MOC poleward, the winds amplify the subsurface warming signal in the region between $40^{\circ}$ and $50^{\circ} \mathrm{S}$ (with a warming maximum over $1 \mathrm{~K}$ ) and suppress the signal at higher and lower latitudes (Fig. 7b). This result is consistent with Fyfe et al. (2007).

We further examine the wind and direct $\mathrm{CO}_{2}$ effects in modifying OHT and its gradient. Consistent with the CMIP5 models (Fig. 8, gray curves), CESM1(CAM5) shows an anomalous equatorward OHT (Fig. 8a, black curve) that peaks around $54^{\circ} \mathrm{S}$ with $\mathrm{OHT}$ divergence and convergence on its poleward and equatorward flanks, respectively (see Fig. 10a, sky-blue curve). This OHT 

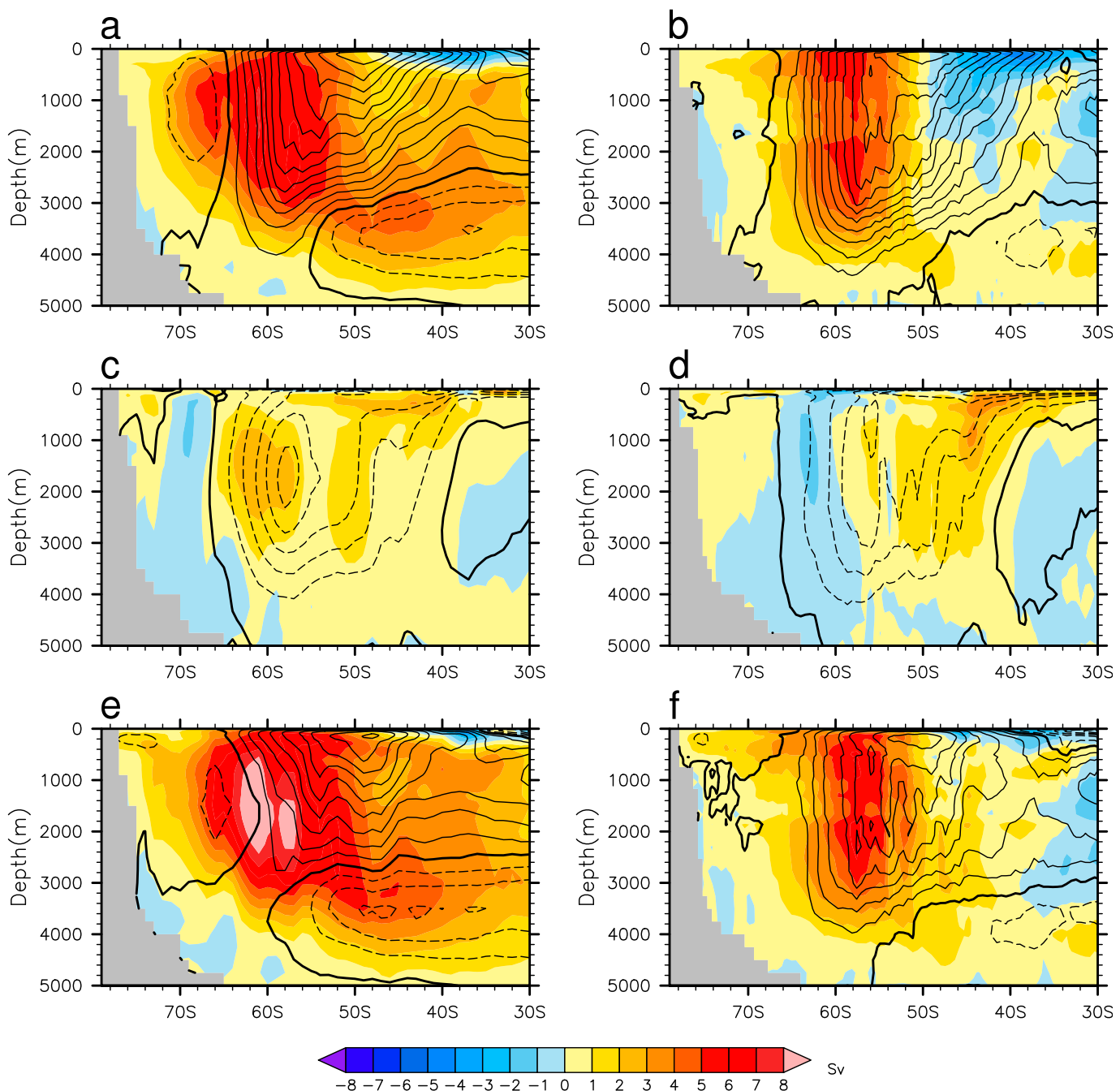

FIG. 4. Changes (shading) and preindustrial annual mean (contours) of (a) $\bar{\psi}$, (c) $\psi^{*}$, and (e) $\psi_{\text {res }}$ in response to quadrupled $\mathrm{CO}_{2}$ for CMIP5 model ensemble mean. (b),(d),(f) As in (a),(c),(e), but for CESM1(CAM5). The contour interval is $3 \mathrm{~Sv}$, with zero contours thickened and solid (dashed) lines for positive (negative) contours.

change is primarily due to the changes in $\overline{\mathrm{OHT}}$ (Fig. $8 \mathrm{~b}$, black curve). The OHT* partially offsets the mean-flow part to the south of $45^{\circ} \mathrm{S}$ but strengthens it to the north (Fig. 8c, black curve). Note here, the increased southward eddy heat transport to the south of $45^{\circ} \mathrm{S}$ does not result from the change of eddy-induced MOC but is mostly accomplished through the advection of temperature anomalies by the climatological eddy-induced MOC. Compared to advective heat transports ( $\overline{\mathrm{OHT}}$ and $\left.\mathrm{OHT}^{*}\right)$, the change in $\mathrm{OHT}^{d}$ is small and localized mostly around $45^{\circ} \mathrm{S}$ (Fig. 8d, black curve).

Using the overriding technique, we split the total $\mathrm{OHT}$ response into the wind-driven and direct $\mathrm{CO}_{2}$-induced parts. Again, the $\overline{\mathrm{OHT}}$ dominates both parts. Polewardintensified surface winds generate a dipole-like $\overline{\mathrm{OHT}}$ change: an anomalous equatorward (poleward) $\overline{\mathrm{OHT}}$ to the south (north) of $45^{\circ} \mathrm{S}$ (Fig. 8b, blue curve). This winddriven $\overline{\mathrm{OHT}}$ change is primarily accomplished through an MOC change. The shift and strengthening of the wind-driven Deacon cell strengthens the MOC and the associated $\overline{\mathrm{OHT}}$ south of $45^{\circ} \mathrm{S}$ and weakens them to the north (Fig. 8b, blue curve). On the other hand, the direct $\mathrm{CO}_{2}$ effect causes an anomalous equatorward $\overline{\mathrm{OHT}}$ in most regions of the Southern Ocean, with a peak at $43^{\circ}-58^{\circ} \mathrm{S}$ (Fig. $8 \mathrm{~b}$, red curve). Unlike its winddriven counterpart, the direct $\mathrm{CO}_{2}$-induced $\overline{\mathrm{OHT}}$ change is due to ocean warming (Fig. 7c). To the north of $62^{\circ} \mathrm{S}$, most of the $\mathrm{CO}_{2}$-induced warming concentrates in the upper $1000 \mathrm{~m}$ (Fig. 7c) and is carried northward by the upper branch of the climatological mean MOC. Comparing the wind-driven and direct $\mathrm{CO}_{2}$-induced $\overline{\mathrm{OHT}}$ changes, we find that 1 ) their 

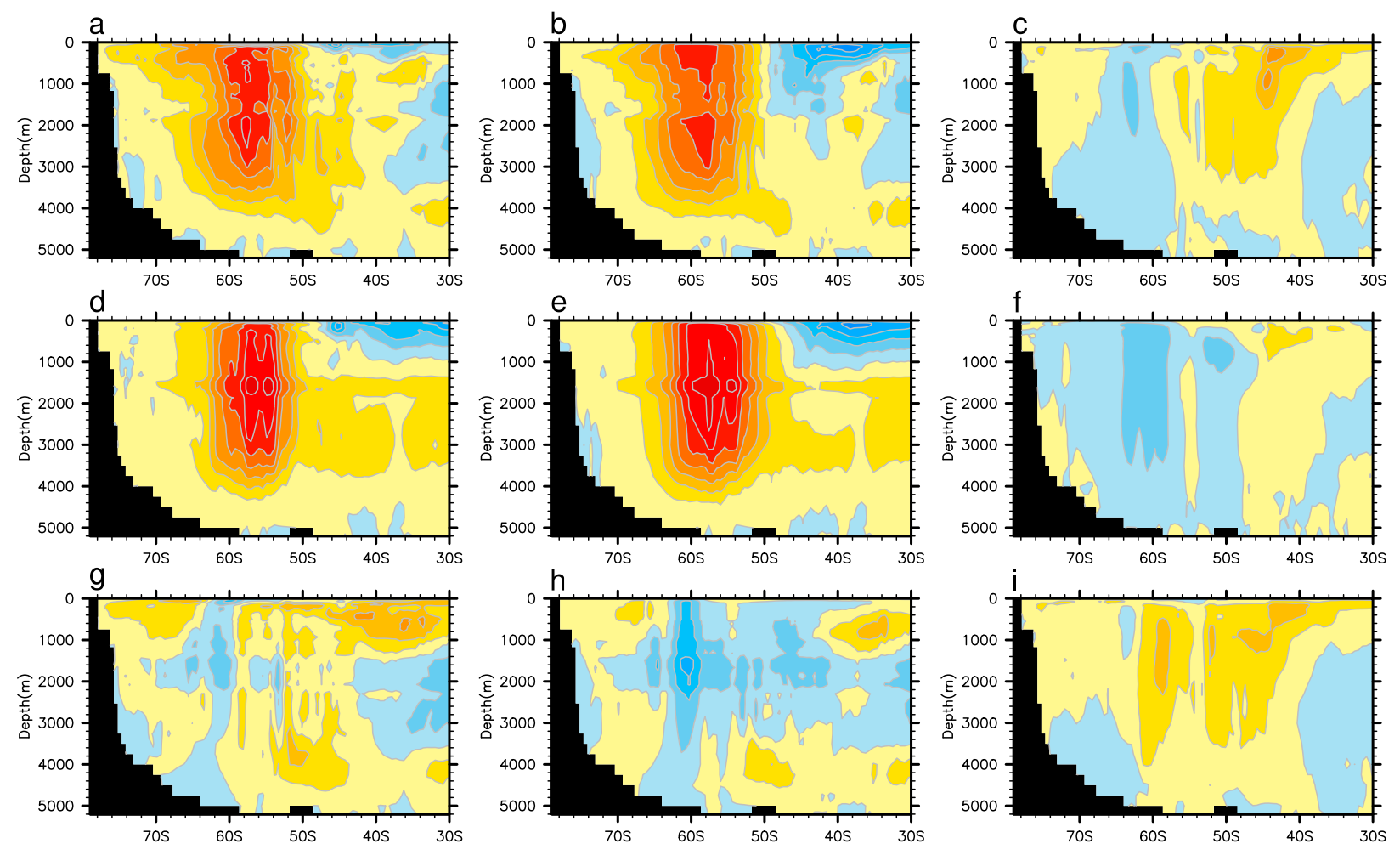

FIG. 5. The total response of (a) residual, (b) Eulerian-mean, and (c) eddy-induced $\psi$ in CESM1(CAM5). (d)-(f) As in (a)-(c), but for Wstr effect. (g)-(i) As in (a)-(c), but for dirCO $\mathrm{Cffect}_{2}$

magnitudes are on the same order (0.1-0.2 PW; $1 \mathrm{PW}=$ $10^{15} \mathrm{~W}$ ) and 2) they both transport heat equatorward up to $45^{\circ} \mathrm{S}$ but work against each other to the north of this latitude (Fig. 8b). These results implicate that the wind and direct $\mathrm{CO}_{2}$ effects are of equal importance in shaping the OHT response over the Southern Ocean.

Besides the OHT variations, surface wind changes also play a pivotal role in shaping SHF and OHU over
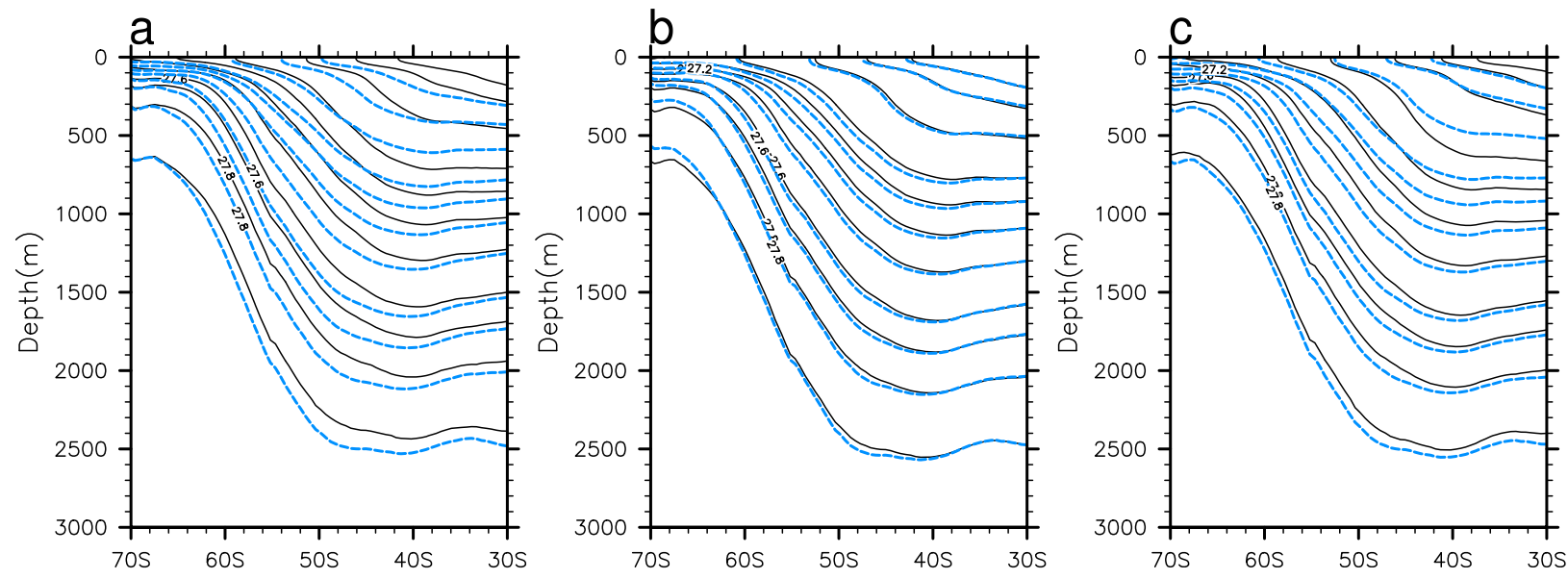

FIG. 6. Zonal mean potential density referenced to the surface $\sigma_{0}\left(\mathrm{~kg} \mathrm{~m}^{-3}\right)$ south of $30^{\circ} \mathrm{S}$ over the upper $3000 \mathrm{~m}$ : (a) CTRL (solid black) and $4 \times \mathrm{CO}_{2}$ (dashed blue); (b) wind stress overriding experiments: $\tau 4 \mathrm{w} 1 \mathrm{c} 4$ (solid black) and $\tau 1 \mathrm{w} 1 \mathrm{c} 4$ (dashed blue); (c) direct $\mathrm{CO}_{2}$ experiments: $\tau 1 \mathrm{w} 1 \mathrm{c} 1$ (solid black) and $\tau 1 \mathrm{w} 1 \mathrm{c} 4$ (dashed blue) for CESM1(CAM5). Both solid black and dashed blue contours in (a) $-(\mathrm{c})$ follow the same contouring levels: $25.6,26,26.4,26.8,27,27.2,27.4,27.6,27.7,27.8$, and $27.9 \mathrm{~kg} \mathrm{~m}^{-3}$. 

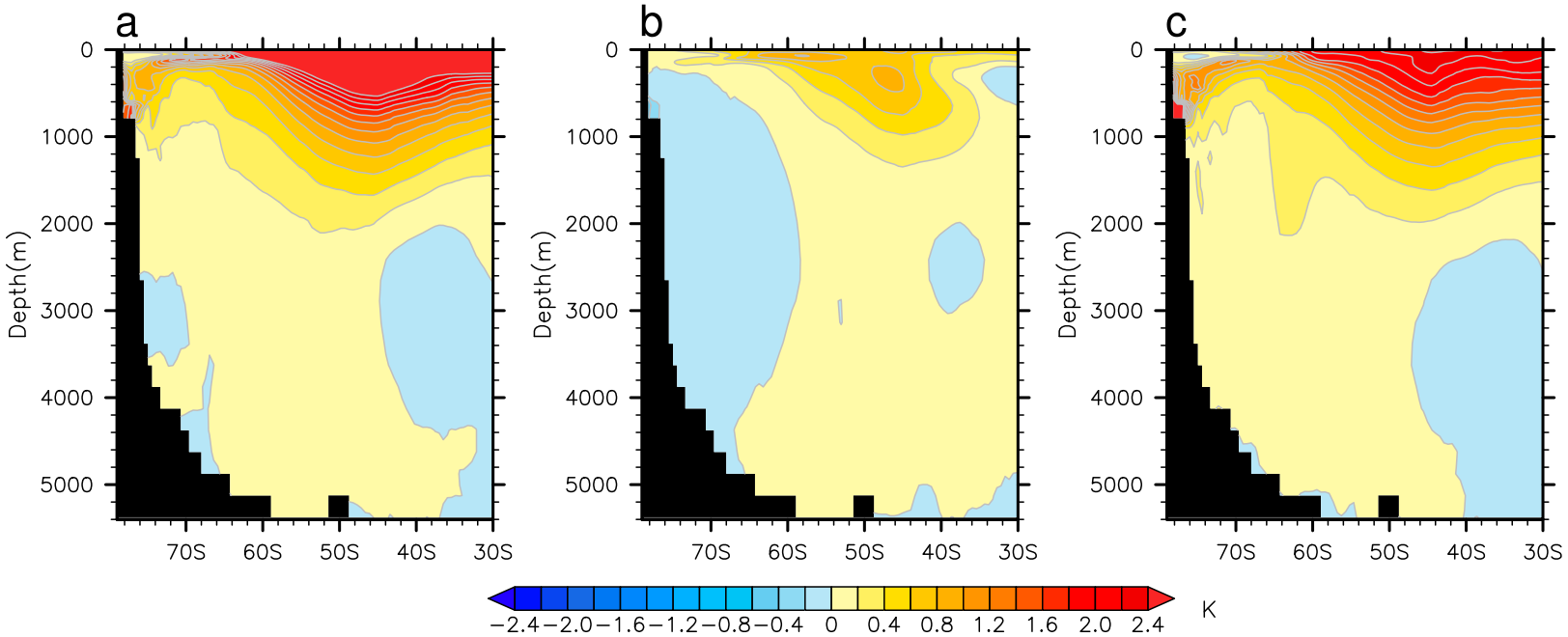

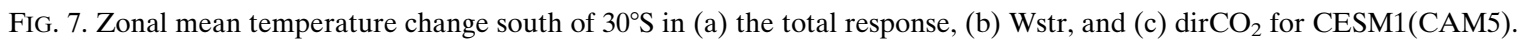

the Southern Ocean. In response to the polewardintensified surface winds, the ocean gains heat (positive anomalous SHF) around $60^{\circ} \mathrm{S}$ (Figs. 9c,d), which is primarily related to an OHT divergence induced by enhanced wind-driven MOC (a point to return later). Meanwhile, the ocean loses heat (negative anomalous $\mathrm{SHF}$ ) around $45^{\circ} \mathrm{S}$. This is because anomalous upperlevel convergent and subducting motion there warms the ocean surface and leads to oceanic heat loss via sensible and latent heat fluxes (Fig. 9d, blue curve).
In contrast, the direct $\mathrm{CO}_{2}$ effect brings about net heat gain over the Southern Ocean (Figs. 9e,f), with most heat entering the upwelling region (around $60^{\circ} \mathrm{S}$ ) via sensible and latent heat fluxes (Fig. 9f, blue curve). This is predominantly the result of passive heat uptake by the background mean Southern Ocean circulation, the salient characteristic of which is a monotonic decrease with depth of temperature anomalies below the mixed layer in the open ocean. As the direct $\mathrm{CO}_{2}$-induced MOC change is secondary (although the eddy part is still
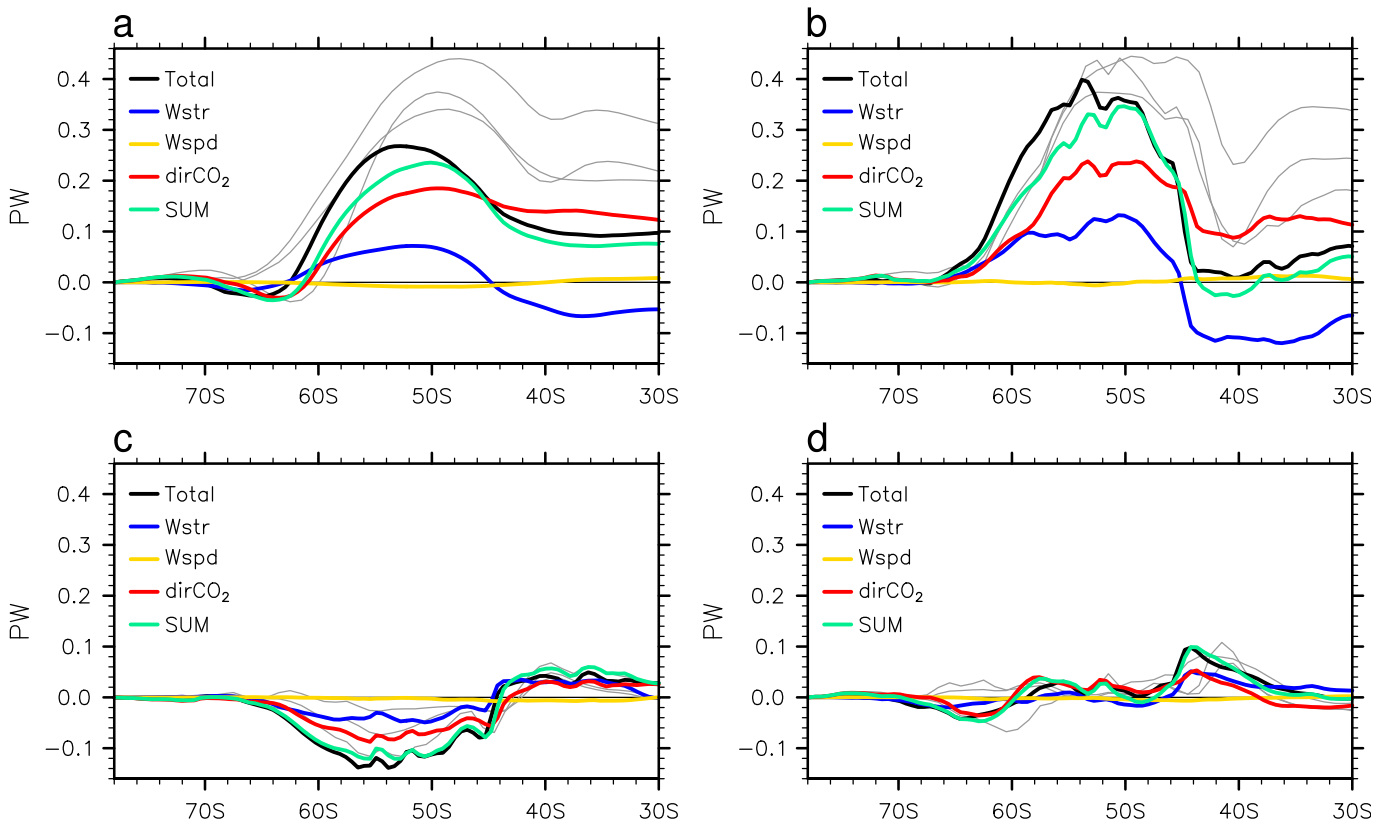

FIG. 8. Changes of (a) meridional OHT and its (b) Eulerian-mean, (c) eddy-induced, and (d) diffusive compo-

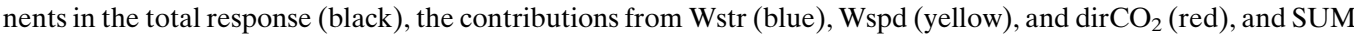
(light green) for CESM1(CAM5). The total responses (gray) for CMIP5 models are also included in each panel. 

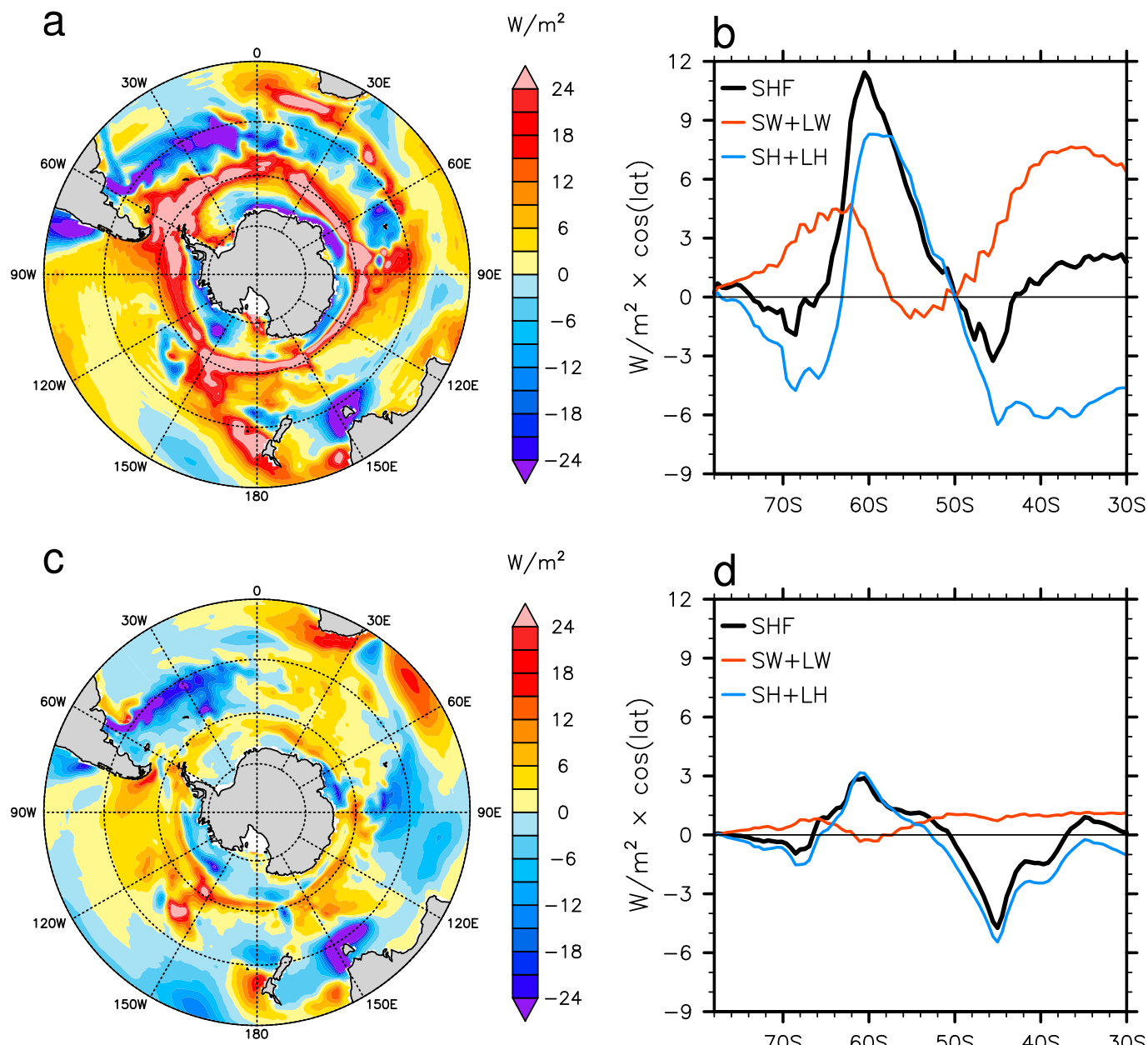

$\mathrm{W} / \mathrm{m}^{2}$
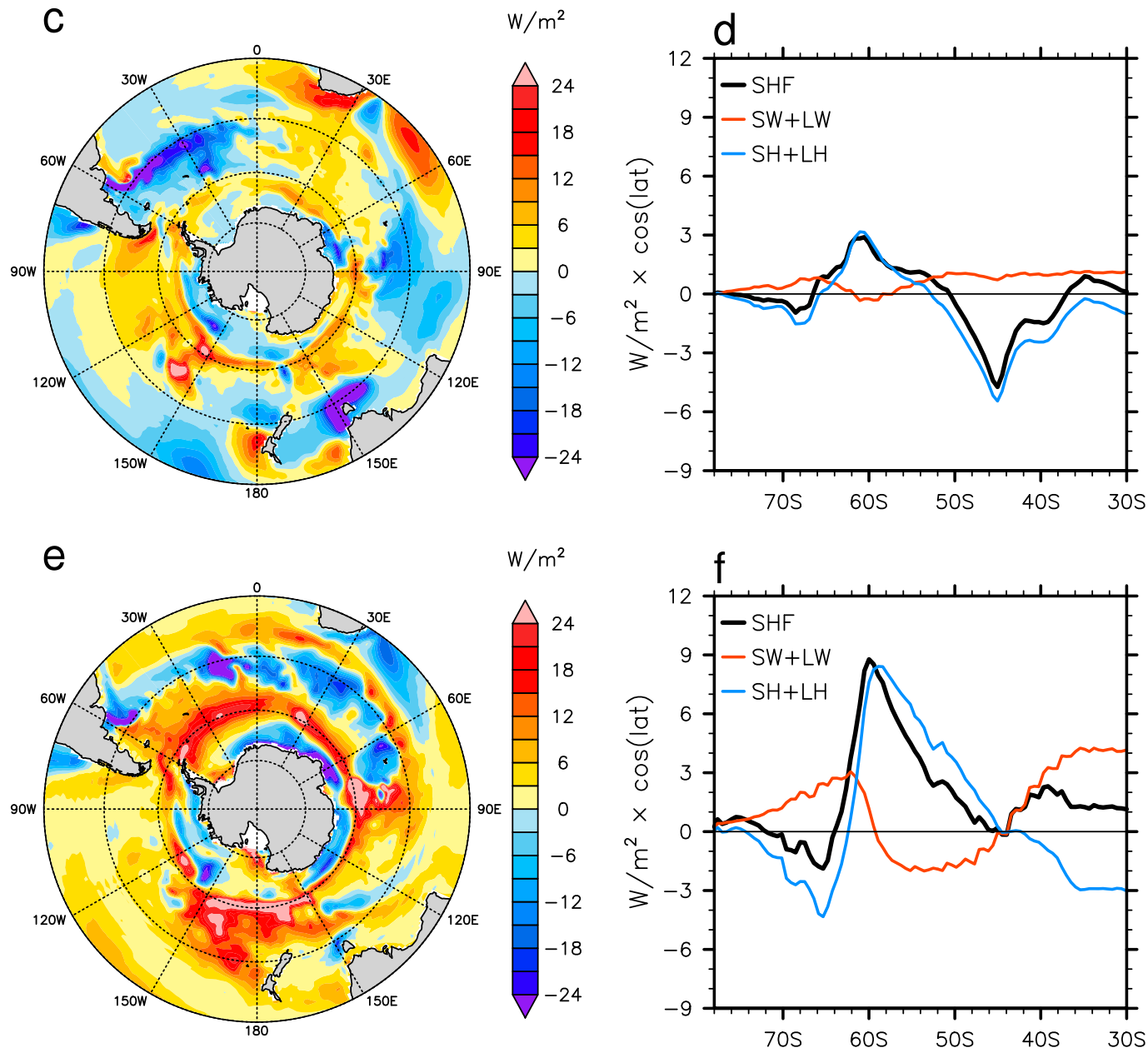

FIG. 9. SHF change over the Southern Ocean in the (a) total, (c) Wstr, and (e) dirCO $\mathrm{C}_{2}$ responses for CESM1 (CAM5). Zonal-mean changes of SHF (black), SW + LW (orange-red), and SH + LH (blue) in the (b) total, (d) Wstr, and (f) dirCO 2 responses for CESM1(CAM5). 

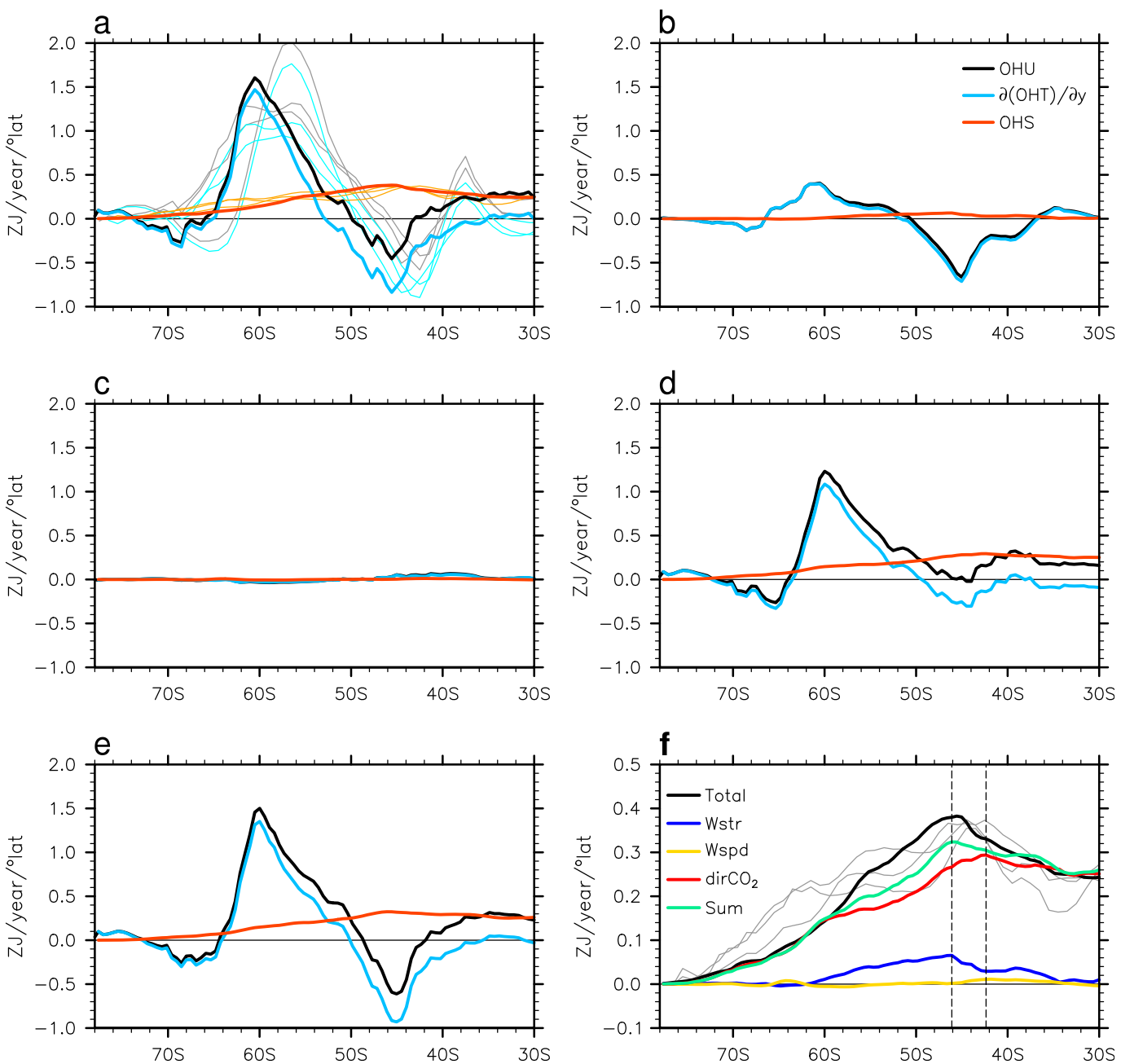

FIG. 10. Heat budget [Eq. (8)]: OHU (black), $\partial(\mathrm{OHT}) / \partial y$ (sky blue), and OHS (orange-red) south of $30^{\circ} \mathrm{S}$ in (a) the total response, the contributions resulting from (b) Wstr, (c) Wspd, and (d) dirCO $\mathrm{O}_{2}$ effects, and (e) the SUM for replication of the total response in CESM1(CAM5). Results from three individual CMIP5 models (OHU is gray, $\partial(\mathrm{OHT}) / \partial y$ is cyan, and OHS is orange) are also presented in (a) as thin curves. OHS is replotted in (f) for the comparison of the total response (black), the contributions resulting from Wstr (blue), Wspd (yellow), and dirCO (red) effects, and SUM (light green) for CESM1(CAM5) as well as the total response (gray) for CMIP5 models.

important), we could treat the direct $\mathrm{CO}_{2}$-induced part as passive uptake [note here that this treatment is only approximately valid in the Southern Ocean, since the increasing $\mathrm{CO}_{2}$ hardly alters the residual MOC in the Southern Ocean but can greatly change the MOC in the Atlantic; Liu et al. 2017; see also Marshall et al. (2015) for the rationale of this treatment] and the winddriven part as active uptake. This is supported by a recent study (Garuba et al. 2018) that showed that passive ocean tracers coupled to the atmosphere under increasing $\mathrm{CO}_{2}$ can produce almost the same pattern as that of the direct $\mathrm{CO}_{2}$-induced heat uptake here (Fig. 9e), while active heat uptake derived from tracer experiments is very similar to the wind-driven heat uptake (Fig. 9c). Overall, comparing the wind-driven, the direct $\mathrm{CO}_{2}$-induced, and the total
OHU, we find that 1) the wind-driven part accounts for the total heat loss around $45^{\circ} \mathrm{S}$ and 2) the wind-driven and direct $\mathrm{CO}_{2}$-induced parts explain about one-third and twothirds of the total heat gain around $60^{\circ} \mathrm{S}$, respectively (Figs. 9b,d,f, black curves).

Based on Eq. (8), we can close the heat budget and quantify the contributions of the wind-driven and direct $\mathrm{CO}_{2}$-induced feedbacks to Southern Ocean heat uptake and storage. We first focus on the heat budget in the total response where the maximum surface heat gain at around $60^{\circ} \mathrm{S}$ (Fig. 10a, black curve) is balanced mostly by an anomalous OHT divergence (Fig. 10a, sky-blue curve). This result is consistent with (Armour et al. 2016), indicating that the region where most heat enters is not the place where the ocean warms most. Following an 
anomalous equatorward OHT (Fig. 8a), most of the heat is carried and stored north of $60^{\circ} \mathrm{S}$ (Fig. 10a, orange-red curve). The maximum of OHS occurs at $45^{\circ} \mathrm{S}$ at a rate of $0.38 \mathrm{ZJ} \mathrm{yr}^{-1}\left(1 \mathrm{ZJ}=10^{21} \mathrm{~J}\right)$. It is significant that the $\mathrm{OHS}$ patterns are similar between CESM1(CAM5) (Fig. 10a, orange-red curve) and the CMIP5 models (Fig. 10a, orange curves), although the OHU and OHT patterns are recognizably different among these models (Fig. 10a).

To further quantify the contributions from the winddriven and direct $\mathrm{CO}_{2}$-induced processes, we examine the heat budgets related to both processes. We find that the poleward-shifted and intensified surface winds displace and strengthen the Deacon cell and residual MOC, thus leading to an OHT divergence (convergence) around $60^{\circ} \mathrm{S}\left(45^{\circ} \mathrm{S}\right)$. Meanwhile, the wind-induced feedback brings about a heat gain (loss) at $60^{\circ} \mathrm{S}\left(45^{\circ} \mathrm{S}\right)$ in the surface flux (Fig. 10b). As a result, the wind-driven OHS peaks at $46^{\circ} \mathrm{S}$ at a rate of $0.07 \mathrm{ZJ} \mathrm{yr}^{-1}\left({ }^{\circ} \text { lat }\right)^{-1}$ and contributes to about one-fifth of the total OHS maximum (Fig. 10f, blue curve). When we compute the heat budget over the Southern Ocean (from the Antarctic coast to $34^{\circ} \mathrm{S}$ and from ocean surface to the bottom), we find that the wind-driven $\mathrm{OHU}$ is $-0.9 \mathrm{ZJ} \mathrm{yr}^{-1}$, which means that the poleward-shifted, intensified winds act to release heat from ocean to atmosphere. At the same time, the wind changes induce an anomalous OHT of $-1.9 \mathrm{ZJ} \mathrm{yr}^{-1}$ across $34^{\circ} \mathrm{S}$ by altering the $\operatorname{MOC}\left(\psi_{\mathrm{res}}\right)$. Not only does this anomalous poleward heat transport compensate the wind-induced heat loss at the ocean surface, but it also results in a net heat storage of $1.0 \mathrm{ZJ} \mathrm{yr}^{-1}$ that accounts for about one-eighth of basinintegrated OHS.

On the other hand, the direct $\mathrm{CO}_{2}$-induced warming brings about an anomalous OHT divergence and a maximum heat gain at $60^{\circ} \mathrm{S}$ (Fig. 10d). This combination leads to an OHS peaking at $42^{\circ} \mathrm{S}$ at a rate of $0.30 \mathrm{ZJ} \mathrm{yr}^{-1}$ $\left({ }^{\circ} \text { lat }\right)^{-1}$, which yields about four-fifths of the total OHS maximum (Fig. 10f, red curve). The basin-integrated heat budget further shows that the direct $\mathrm{CO}_{2}$ effect induces an $\mathrm{OHU}$ of $11.0 \mathrm{ZJ} \mathrm{yr}^{-1}$ at the ocean surface and an OHT of $4.2 \mathrm{ZJ} \mathrm{yr}^{-1}$ out of the basin across $34^{\circ} \mathrm{S}$, leaving a net heat storage of $6.8 \mathrm{ZJ} \mathrm{yr}^{-1}$ that accounts for about seven-eighths of basin-integrated OHS over the Southern Ocean. It is noteworthy that the peak of the wind-driven $\mathrm{OHS}$ is located about $4^{\circ}$ south of the peak of the direct $\mathrm{CO}_{2}$-induced OHS (Fig. 10f); that is, the poleward-intensified winds act to distribute oceanic heat to a more poleward location in a warming climate.

\section{Conclusions and discussion}

In this study, we explore the Southern Ocean heat uptake, redistribution, and storage in response to quadrupled $\mathrm{CO}_{2}$. We first identify the general characteristics of climate response from 10 CMIP5 climate models, which show that most heat enters the Southern Ocean around $60^{\circ} \mathrm{S}$ but is stored around $45^{\circ} \mathrm{S}$, as consistent with other studies (e.g., Frölicher et al. 2015; Armour et al. 2016). This result suggests that heat in the ocean interior is redistributed by the MOC, which, in turn, is related to surface wind changes. To isolate and quantify the wind effect, we apply an overriding technique to a climate model, CESM1(CAM5), and decompose the total climate response into the wind-driven and direct $\mathrm{CO}_{2}$-induced parts. For the wind-driven part, the poleward-intensified surface winds shift and strengthen the Deacon cell and hence the residual MOC, which generates an anomalous OHT divergence (convergence) at $60^{\circ} \mathrm{S}\left(45^{\circ} \mathrm{S}\right)$. Further, in response to wind-driven circulation change, the Southern Ocean gains heat around $60^{\circ} \mathrm{S}$ but loses heat around $45^{\circ} \mathrm{S}$. As a result, the wind-driven OHS peaks at $46^{\circ} \mathrm{S}$ at a rate of $0.07 \mathrm{ZJ} \mathrm{yr}^{-1}\left({ }^{\circ} \text { lat }\right)^{-1}$ and contributes to about one-fifth of the total OHS maximum. On the other hand, the direct $\mathrm{CO}_{2}$ effect barely modifies the residual MOC but accounts for most temperature variations, leading to anomalous equatorward OHT and heat gain in most regions of the Southern Ocean. The heat gain is maximum at $60^{\circ} \mathrm{S}$ where the anomalous OHT diverges. As a result, the direct $\mathrm{CO}_{2}$-induced OHS peaks at $42^{\circ} \mathrm{S}$ instead of $60^{\circ} \mathrm{S}$, at a rate of $0.30 \mathrm{ZJ} \mathrm{yr}^{-1}$ ( ${ }^{\circ}$ lat) $)^{-1}$ and contributes to four-fifths of the total OHS maximum.

Another interesting result of our study is the weakening of the eddy-induced MOC over the Southern Ocean in response to quadrupled $\mathrm{CO}_{2}$ (Figs. 4c,d). In both CESM1(CAM5) and CMIP5 models, the eddyinduced MOC weakens when Southern Hemisphere westerly winds strengthen and shift poleward. Based on the CESM1(CAM5) overriding experiments, we find that the weakening of the eddy-induced MOC is primarily caused by the direct $\mathrm{CO}_{2}$ effect. Two processes compete under quadrupled $\mathrm{CO}_{2}$. On the one hand, the poleward-intensified winds enhance isopycnal tilting (Fig. 6b) and increase the eddy-induced MOC by $1 \mathrm{~Sv}$ (Fig. 5f). On the other hand, the direct $\mathrm{CO}_{2}$-induced buoyancy change suppresses isopycnal tilting (Fig. 6b) and decreases the eddy-induced MOC by $2 \mathrm{~Sv}$ (Fig. 5f), which overshadows the former effect, manifesting in a weaker eddy-induced MOC.

Our heat budget analyses on CESM1(CAM5) and CMIP5 models reveal that both mean flow and eddy could be important to Southern Ocean heat uptake and redistribution. Particularly, the peak of the OHT divergence around $60^{\circ} \mathrm{S}$ is primarily driven by an enhanced mean-flow part rather than a reduced eddy part, which is in agreement with those previous studies identifying this 
mechanism (Cai et al. 2010; Kuhlbrodt and Gregory 2012; Marshall and Zanna 2014; Bryan et al. 2014; Exarchou et al. 2015). On the other hand, both eddy (plus diffusion) and mean-flow parts contribute to an anomalous northward OHT to the north of $45^{\circ} \mathrm{S}$ and hence an OHT convergence around $45^{\circ} \mathrm{S}$. This is consistent with Morrison et al. (2016).

We use a quadrupled $\mathrm{CO}_{2}$ forcing in this study for the purpose of a large signal-to-noise ratio and a clean single-factor view of future warming climate. In the real world, many other factors, such as ozone variations, can also play a role in Southern Ocean heat uptake and redistribution. As discussed in the introduction, a large portion of wind change (and hence the wind effect) can be attributed to ozone depletion during recent years. Nevertheless, the ozone is predicted to recover in the representative concentration pathway (RCP) scenarios so that the ozone effect will become increasingly weak, which justifies the usage of a single $\mathrm{CO}_{2}$ increase as a good approximation to future climate forcing. Here, we suspect that some climate responses, such as the weakened eddy-induced MOC, may depend on the strength or the form of forcing. In our case, a quadrupled $\mathrm{CO}_{2}$ is a strong forcing that allows a large buoyancy flux change to overcome the wind effect and dominate in regulating isopycnal tilting and baroclinicity over the Southern Ocean. However, the response of eddy-induced MOC is likely subject to change if under a weaker $\mathrm{CO}_{2}$ forcing or a combined forcing with ozone change.

We show a nice agreement between CESM1(CAM5) and other CMIP5 models in the response of Southern Ocean heat uptake, redistribution, and storage under quadrupled $\mathrm{CO}_{2}$ forcing. This is indeed significant since CMIP5 models are known to have biases in their climatological temperature gradients and background OHC (e.g., Schneider and Deser 2018; Kostov et al. 2017). The agreement between CESM1(CAM5) and the other CMIP5 models may be due to the dominant role of the direct $\mathrm{CO}_{2}$ effect that accounts for $80 \%$ of OHS. Any model biases in the climatological temperature gradients would affect only the remaining $20 \%$ of OHS because of wind-induced changes.

In this study, we do not discuss the effect of sea ice on Southern Ocean heat uptake and redistribution because this effect is not robust in CESM1(CAM5). Previous studies (e.g., Bitz et al. 2006) suggest that the sea ice response around Antarctica to increasing $\mathrm{CO}_{2}$ causes surface freshening and weakened convection, which further reduces the vertical and meridional temperature gradients, leading to a deep warming below $500 \mathrm{~m}$ that extends to several kilometers deep and spreads equatorward from the Antarctic sea ice area. This deepwarming pattern is present in some of the CMIP5 models (Fig. 2e) but not in CESM1(CAM5) (Fig. 2f). In CESM1(CAM5), the warming is limited to the upper $1000 \mathrm{~m}$ close to the coast of Antarctica. Exploring the sea ice effect will be important in our future work.

Acknowledgments. We thank three anonymous reviewers for their valuable comments that helped improve the manuscript. This work was supported by the National Science Foundation (AGS-1249145 and OPP1741841), the DOE Office of Science (DE-SC0016538), and the U. S. Department of Energy Office of Science as part of the Regional and Global Climate Modeling program. The CMIP5 data are publicly available through the portal of the U.S. Earth System Grid Center for Enabling Technologies on the page http://pcmdi9.1lnl.gov/.

\section{REFERENCES}

Abernathey, R., J. Marshall, and D. Ferreira, 2011: The dependence of Southern Ocean meridional overturning on wind stress. J. Phys. Oceanogr., 41, 2261-2278, https://doi.org/ 10.1175/JPO-D-11-023.1.

Armour, K. C., J. Marshall, J. R. Scott, A. Donohoe, and E. R. Newsom, 2016: Southern Ocean warming delayed by circumpolar upwelling and equatorward transport. Nat. Geosci., 9, 549-554, https://doi.org/ 10.1038/ngeo2731.

Banks, H. T., and J. M. Gregory, 2006: Mechanisms of ocean heat uptake in a coupled climate model and the implications for tracer based predictions of ocean heat uptake. Geophys. Res. Lett., 33, L07608, https://doi.org/10.1029/2005GL025352.

Bishop, S. P., P. R. Gent, F. O. Bryan, A. F. Thompson, M. C. Long, and R. Abernathey, 2016: Southern Ocean overturning compensation in an eddy-resolving climate simulation. J. Phys. Oceanogr., 46, 1575-1592, https://doi.org/10.1175/JPO-D-15-0177.1.

Bitz, C. M., P. R. Gent, R. A. Woodgate, M. M. Holland, and R. Lindsay, 2006: The influence of sea ice on ocean heat uptake in response to increasing $\mathrm{CO}_{2}$. J. Climate, 19, 2437-2450, https://doi.org/10.1175/JCLI3756.1.

Bryan, F. O., P. R. Gent, and R. Tomas, 2014: Can Southern Ocean eddy effects be parameterized in climate models? J. Climate, 27, 411-425, https://doi.org/10.1175/JCLI-D-12-00759.1.

Bryan, K., S. Manabe, and M. J. Spelman, 1988: Interhemispheric asymmetry in the transient response of a coupled oceanatmosphere model to a $\mathrm{CO}_{2}$ forcing. J. Phys. Oceanogr., 18, 851-867, https://doi.org/10.1175/1520-0485(1988)018<0851: IAITTR $>2.0 . \mathrm{CO} ; 2$.

Cai, W., T. Cowan, S. Godfrey, and S. Wijffels, 2010: Simulations of processes associated with the fast warming rate of the southern midlatitude ocean. J. Climate, 23, 197-206, https://doi.org/ 10.1175/2009JCLI3081.1.

Chen, X., and K.-K. Tung, 2014: Varying planetary heat sink led to global-warming slowdown and acceleration. Science, 345, 897903, https://doi.org/10.1126/science.1254937.

Church, J. A., and Coauthors, 2011: Revisiting the earth's sea-level and energy budgets from 1961 to 2008. Geophys. Res. Lett., 38, L18601, https://doi.org/10.1029/2011GL048794.

D. Monselesan, J. M. Gregory, and B. Marzeion, 2013: Evaluating the ability of process based models to project sealevel change. Environ. Res. Lett., 8, 014051, https://doi.org/ 10.1088/1748-9326/8/1/014051. 
Dalan, F., P. H. Stone, and A. P. Sokolov, 2005: Sensitivity of the ocean's climate to diapycnal diffusivity in an EMIC. Part II: Global warming scenario. J. Climate, 18, 2482-2496, https:// doi.org/10.1175/JCLI3412.1.

Döös, K., and D. J. Webb, 1994: The Deacon cell and the other meridional cells of the Southern Ocean. J. Phys. Oceanogr., 24, 429-442, https://doi.org/10.1175/1520-0485(1994)024<0429: TDCATO $>2.0 . \mathrm{CO} ; 2$.

Downes, S. M., and A. M. Hogg, 2013: Southern Ocean circulation and eddy compensation in CMIP5 models. J. Climate, 26, 7198-7220, https://doi.org/10.1175/JCLI-D-12-00504.1.

Durack, P. J., P. J. Gleckler, F. W. Landerer, and K. E. Taylor, 2014: Quantifying underestimates of long-term upper-ocean warming. Nat. Climate Change, 4, 999-1005, https://doi.org/ 10.1038/nclimate2389.

Exarchou, E., T. Kuhlbrodt, J. M. Gregory, and R. S. Smith, 2015: Ocean heat uptake processes: A model intercomparison. J. Climate, 28, 887-908, https://doi.org/10.1175/JCLI-D-14-00235.1.

Farneti, R., T. L. Delworth, A. J. Rosati, S. M. Griffies, and F. Zeng, 2010: The role of mesoscale eddies in the rectification of the Southern Ocean response to climate change. J. Phys. Oceanogr., 40, 1539-1557, https://doi.org/10.1175/2010JPO4353.1.

Ferreira, D., J. Marshall, C. M. Bitz, S. Solomon, and A. Plumb, 2015: Antarctic Ocean and sea ice response to ozone depletion: A two-time-scale problem. J. Climate, 28, 1206-1226, https://doi.org/10.1175/JCLI-D-14-00313.1.

Frölicher, T. L., J. L. Sarmiento, D. J. Paynter, J. P. Dunne, J. P. Krasting, and M. Winton, 2015: Dominance of the Southern Ocean in anthropogenic carbon and heat uptake in CMIP5 models. J. Climate, 28, 862-886, https://doi.org/ 10.1175/JCLI-D-14-00117.1.

Fyfe, J. C., 2006: Southern Ocean warming due to human influence. Geophys. Res. Lett., 33, L19701, https://doi.org/10.1029/ 2006GL027247.

, O. A. Saenko, K. Zickfeld, M. Eby, and A. J. Weaver, 2007: The role of poleward-intensifying winds on Southern Ocean warming. J. Climate, 20, 5391-5400, https://doi.org/10.1175/ 2007JCLI1764.1.

Garuba, O. A., J. Lu, F. Liu, and H. A. Singh, 2018: The active role of the ocean in the temporal evolution of climate sensitivity. Geophys. Res. Lett., 45, 306-315, https://doi.org/10.1002/ 2017 GL075633.

Gent, P. R., and J. C. McWilliams, 1990: Isopycnal mixing in ocean circulation models. J. Phys. Oceanogr., 20, 150-155, https:// doi.org/10.1175/1520-0485(1990)020<0150:IMIOCM >2.0.CO;2.

—_, and G. Danabasoglu, 2011: Response to increasing Southern Hemisphere winds in CCSM4. J. Climate, 24, 4992-4998, https://doi.org/10.1175/JCLI-D-10-05011.1.

Gille, S. T., 2002: Warming of the Southern Ocean since the 1950s. Science, 295, 1275-1277, https://doi.org/10.1126/science.1065863.

Gillett, N. P., and D. W. J. Thompson, 2003: Simulation of recent Southern Hemisphere climate change. Science, 302, 273-275, https://doi.org/10.1126/science.1087440.

Gregory, J. M., 2000: Vertical heat transports in the ocean and their effect on time-dependent climate change. Climate Dyn., 16, 501-515, https://doi.org/10.1007/s003820000059.

— , and Coauthors, 2001: Comparison of results from several AOGCMs for global and regional sea-level change 1900-2100. Climate Dyn., 18, 225-240, https://doi.org/10.1007/s003820100180.

Griffies, S. M., and Coauthors, 2015: Impacts on ocean heat from transient mesoscale eddies in a hierarchy of climate models. J. Climate, 28, 952-977, https://doi.org/10.1175/ JCLI-D-14-00353.1.
Hallberg, R., and A. Gnanadesikan, 2006: The role of eddies in determining the structure and response of the wind-driven Southern Hemisphere overturning: Results from the Modeling Eddies in the Southern Ocean (MESO) project. J. Phys. Oceanogr., 36, 2232-2252, https://doi.org/10.1175/JPO2980.1.

Hieronymus, M., and J. Nycander, 2013: The budgets of heat and salinity in NEMO. Ocean Modell., 67, 28-38, https://doi.org/ 10.1016/j.ocemod.2013.03.006.

Hogg, A. M. C., M. P. Meredith, J. R. Blundell, and C. Wilson, 2008: Eddy heat flux in the Southern Ocean: Response to variable wind forcing. J. Climate, 21, 608-620, https://doi.org/ 10.1175/2007JCLI1925.1.

Holland, M. M., D. A. Bailey, B. P. Briegleb, B. Light, and E. Hunke, 2012: Improved sea ice shortwave radiation physics in CCSM4: The impact of melt ponds and aerosols on Arctic sea ice. J. Climate, 25, 1413-1430, https://doi.org/10.1175/ JCLI-D-11-00078.1.

Huang, B., P. H. Stone, A. P. Sokolov, and I. V. Kamenkovich, 2003: The deep-ocean heat uptake in transient climate change. J. Climate, 16, 1352-1363, https://doi.org/10.1175/ 1520-0442-16.9.1352.

Hurrell, J. W., and Coauthors, 2013: The Community Earth System Model: A framework for collaborative research. Bull. Amer. Meteor. Soc., 94, 1339-1360, https://doi.org/10.1175/BAMS-D12-00121.1.

Hwang, Y.-T., S.-P. Xie, C. Deser, and S. M. Kang, 2017: Connecting tropical climate change with Southern Ocean heat uptake. Geophys. Res. Lett., 44, 9449-9457, https://doi.org/ 10.1002/2017GL074972.

Kostov, Y., J. Marshall, U. Hausmann, K. C. Armour, D. Ferreira, and M. M. Holland, 2017: Fast and slow responses of Southern Ocean sea surface temperature to SAM in coupled climate models. Climate Dyn., 48, 1595-1609, https://doi.org/10.1007/ s00382-016-3162-z.

Kuhlbrodt, T., and J. M. Gregory, 2012: Ocean heat uptake and its consequences for the magnitude of sea level rise and climate change. Geophys. Res. Lett., 39, L18608, https://doi.org/ 10.1029/2012GL052952.

Large, W. G., J. C. McWilliams, and S. C. Doney, 1994: Oceanic vertical mixing: A review and a model with a nonlocal boundary layer parameterization. Rev. Geophys., 32, 363-403, https://doi.org/10.1029/94RG01872.

Lawrence, D. M., K. W. Oleson, M. G. Flanner, C. G. Fletcher, P. J. Lawrence, S. Levis, S. C. Swenson, and G. B. Bonan, 2012: The CCSM4 land simulation, 1850-2005: Assessment of surface climate and new capabilities. J. Climate, 25, 22402260, https://doi.org/10.1175/JCLI-D-11-00103.1.

Lin, S.-J., 2004: A "vertically Lagrangian" finite-volume dynamical core for global models. Mon. Wea. Rev., 132, 2293-2307, https:// doi.org/10.1175/1520-0493(2004)132<2293:AVLFDC>2.0.CO;2.

Liu, W., J. Lu, and S.-P. Xie, 2015: Understanding the Indian Ocean response to double $\mathrm{CO}_{2}$ forcing in a coupled model. Ocean Dyn., 65, 1037-1046, https://doi.org/10.1007/s10236-015-0854-6.

_ S.-P. Xie, and J. Lu, 2016: Tracking ocean heat uptake during the surface warming hiatus. Nat. Commun., 7, 10926, https:// doi.org/10.1038/ncomms10926.

,$- \ldots$, Z. Liu, and J. Zhu, 2017: Overlooked possibility of a collapsed Atlantic meridional overturning circulation in warming climate. Sci. Adv., 3, e1601666, https://doi.org/ 10.1126/sciadv.1601666

Lu, J., and B. Zhao, 2012: The role of oceanic feedback in the climate response to doubling $\mathrm{CO}_{2}$. J. Climate, 25, 7544-7563, https://doi.org/10.1175/JCLI-D-11-00712.1. 
Manabe, S., K. Bryan, and M. J. Spelman, 1990: Transient response of a global ocean-atmosphere model to a doubling of atmospheric carbon dioxide. J. Phys. Oceanogr., 20, 722-749, https://doi.org/10.1175/1520-0485(1990)020<0722: TROAGO $>2.0$.CO;2.

__ R. J. Stouffer, M. J. Spelman, and K. Bryan, 1991: Transient responses of a coupled ocean-atmosphere model to gradual changes of atmospheric $\mathrm{CO}_{2}$. Part I: Annual mean response. J. Climate, 4, 785-818, https://doi.org/10.1175/1520-0442 (1991)004<0785:TROACO > 2.0.CO;2.

Marshall, D. P., and L. Zanna, 2014: A conceptual model of ocean heat uptake under climate change. J. Climate, 27, 8444-8465, https://doi.org/10.1175/JCLI-D-13-00344.1.

Marshall, G. J., 2003: Trends in the southern annular mode from observations and reanalyses. J. Climate, 16, 4134-4143, https://doi. org/10.1175/1520-0442(2003)016<4134:TITSAM>2.0.CO;2.

Marshall, J., and T. Radko, 2003: Residual-mean solutions for the Antarctic Circumpolar Current and its associated overturning circulation. J. Phys. Oceanogr., 33, 2341-2354, https://doi.org/ 10.1175/1520-0485(2003)033<2341:RSFTAC $>2.0$.CO;2.

_, J. R. Scott, K. C. Armour, J.-M. Campin, M. Kelley, and A. Romanou, 2015: The ocean's role in the transient response of climate to abrupt greenhouse gas forcing. Climate Dyn., $\mathbf{4 4}$, 2287-2299, https://doi.org/10.1007/s00382-014-2308-0.

Morrison, A. K., O. A. Saenko, A. M. Hogg, and P. Spence, 2013: The role of vertical eddy flux in Southern Ocean heat uptake. Geophys. Res. Lett., 40, 5445-5450, https://doi.org/10.1002/ 2013 GL057706.

_ S. M. Griffies, M. Winton, W. G. Anderson, and J. L. Sarmiento, 2016: Mechanisms of Southern Ocean heat uptake and transport in a global eddying climate model. J. Climate, 29, 2059-2075, https://doi.org/10.1175/JCLI-D-15-0579.1.

Neale, R. B., and Coauthors, 2012: Description of the NCAR Community Atmosphere Model (CAM 5.0). NCAR Tech. Note NCAR/TN-486+STR, 274 pp.

Oke, P. R., and M. H. England, 2004: Oceanic response to changes in the latitude of the Southern Hemisphere subpolar westerly winds. J. Climate, 17, 1040-1054, https://doi.org/10.1175/15200442(2004)017<1040:ORTCIT>2.0.CO;2.

Purkey, S. G., and G. C. Johnson, 2010: Warming of global abyssal and deep Southern Ocean waters between the 1990s and 2000s: Contributions to global heat and sea level rise budgets. J. Climate, 23, 6336-6351, https://doi.org/10.1175/2010JCLI3682.1.

Roemmich, D., J. Church, J. Gilson, D. Monselesan, P. Sutton, and S. Wijffels, 2015: Unabated planetary warming and its ocean structure since 2006. Nat. Climate Change, 5, 240-245, https:// doi.org/10.1038/nclimate2513.

Rose, B. E. J., K. C. Armour, D. S. Battisti, N. Feldl, and D. D. B. Koll, 2014: The dependence of transient climate sensitivity and radiative feedbacks on the spatial pattern of ocean heat uptake. Geophys. Res. Lett., 41, 1071-1078, https://doi.org/ 10.1002/2013GL058955.

Schneider, D. P., and C. Deser, 2018: Tropically driven and externally forced patterns of Antarctic sea ice change: Reconciling observed and modeled trends. Climate Dyn., https://doi. org/10.1007/s00382-017-3893-5, in press.

Sen Gupta, A., and M. H. England, 2006: Coupled ocean-atmosphereice response to variations in the southern annular mode. J. Climate, 19, 4457-4486, https://doi.org/10.1175/JCLI3843.1.

, A. Santoso, A. S. Taschetto, C. C. Ummenhofer, J. Trevena, and M. H. England, 2009: Projected changes to the Southern Hemisphere ocean and sea ice in the IPCC AR4 climate models. J. Climate, 22, 3047-3078, https://doi.org/10.1175/ 2008JCLI2827.1.

Smith, R. D., and Coauthors, 2010: The Parallel Ocean Program (POP) reference manual. Los Alamos National Laboratory Tech. Rep. LAUR-10-01853, 140 pp.

Spence, P., J. C. Fyfe, A. Montenegro, and A. J. Weaver, 2010: Southern Ocean response to strengthening winds in an eddypermitting global climate model. J. Climate, 23, 5332-5343, https://doi.org/10.1175/2010JCLI3098.1.

Swart, N. C., and J. C. Fyfe, 2012: Observed and simulated changes in the Southern Hemisphere surface westerly wind-stress. Geophys. Res. Lett., 39, L16711, https://doi.org/10.1029/ 2012GL052810.

Taylor, K. E., R. J. Stouffer, and G. A. Meehl, 2012: An overview of CMIP5 and the experiment design. Bull. Amer. Meteor. Soc., 93, 485-498, https://doi.org/10.1175/BAMS-D-11-00094.1.

Thompson, D. W. J., and S. Solomon, 2002: Interpretation of recent Southern Hemisphere climate change. Science, 296, 895-899, https://doi.org/10.1126/science.1069270.

van der Veen, C. J., 1988: Projecting future sea level. Surv. Geophys., 9, 389-418, https://doi.org/10.1007/BF01901630.

Winton, M., K. Takahashi, and I. M. Held, 2010: Importance of ocean heat uptake efficacy to transient climate change. J. Climate, 23, 2333-2344, https://doi.org/10.1175/2009JCLI3139.1.

, S. M. Griffies, B. L. Samuels, J. L. Sarmiento, and T. L. Frölicher, 2013: Connecting changing ocean circulation with changing climate. J. Climate, 26, 2268-2278, https://doi.org/10.1175/ JCLI-D-12-00296.1.

Wolfe, C. L., and P. Cessi, 2010: What sets the strength of the middepth stratification and overturning circulation in eddying ocean models? J. Phys. Oceanogr., 40, 1520-1538, https:// doi.org/10.1175/2010JPO4393.1.

Xie, P., and G. K. Vallis, 2012: The passive and active nature of ocean heat uptake in idealized climate change experiments. Climate Dyn., 38, 667-684, https://doi.org/10.1007/ s00382-011-1063-8. 